\title{
The severity of wheat yield crises on eight Spanish farms, 1700-1774
}

\author{
Enrique Llopis, Elvira Alonso, Paloma Fontanillo, Sara Méndez, \\ JAVIER RAMOS \& ANA ToYos
}

KEYWORDS: yields, crises, wheat, $18^{\text {th }}$ century.

JEL CODES: N01, N13, N53, N93.

he main purpose of this article is to measure the severity of the wheat yield
crises that occurred during the first three quarters of the $18^{\text {th }}$ century, using
records from eight farms and estates in Extremadura, Castile and Andalusia. Specifically, the research is based on account books from several monasteries and the Chapter of the Cordoba Cathedral. We have developed an indicator that considers yield drops in the years of sterility and, where appropriate, the magnitude of cereal deficits during the three-year periods before and after the crises. Our two most relevant conclusions indicate that: 1) the most disastrous cereal crops were obtained in the first quarter of the $18^{\text {th }}$ century; and 2) the decreased severity of the crises in the second and third quarters corresponded more to the mitigation of yield deficits just before and after the years of sterility than to a moderation in their drop during the same periods of scarcity. 


\section{La gravedad de las crisis de rendimientos del trigo en ocho granjas españolas, 1700-1774}

\section{PALABRAS CLAVE: rendimientos, crisis, trigo, siglo XVIII.}

\section{CÓDIGOS JEL: N01, N13, N53, N93.}

$E$ objetivo fundamental de este trabajo radica en la medición de la trayectoria de la gravedad de las crisis de rendimientos en ocho granjas y cortijos extremeños, castellanos y andaluces en los tres primeros cuartos del siglo XVIII. La investigación se ha basado en los libros de cuentas de varios monasterios y del cabildo de la catedral de Córdoba. Para afrontar el problema planteado, hemos elaborado un indicador que contempla las caídas de rendimientos en los años de esterilidad, así como, en su caso, la magnitud de los déficits cerealistas en los trienios anteriores y posteriores a los años de crisis. Las conclusiones más relevantes de esta investigación son: a) los desastres cerealistas alcanzaron su mayor envergadura en el primer cuarto del siglo XVIII; y b) la menor gravedad de las crisis desde la década de 1720 obedeció más a la mitigación de los déficits en los rendimientos en los años inmediatamente anteriores y posteriores a los de esterilidad que a la moderación de sus caídas en los años de cosechas cortas y muy cortas.

Received: 2018-09-02 - Revised: 2019-04-08 - Accepted: 2019-04-09

Enrique Llopis [orcid.org/0000-0001-5862-3508] es catedrático de Historia e Instituciones Económicas en la Universidad Complutense de Madrid. Dirección para correspondencia: Departamento de Economía Aplicada, Estructura e Historia, Facultad de Ciencias Económicas y Empresariales, Universidad Complutense de Madrid, Campus de Somosaguas 28223, Pozuelo de Alarcón (España).C.e.: llopisagelan@ccee.ucm.es

Elvira Alonso es estudiante del Doble Grado en Economía y Matemáticas y Estadística en la Universidad Complutensede Madrid.C.e.:elvialon@ucm.es

Paloma Fontanillo es estudiante del Doble Grado en Economía y Matemáticas y Estadística en la Universidad Complutense de Madrid. C. e.:pfontani@ucm.es

Sara Méndez es estudiante del Doble Grado en Economía y Matemáticas y Estadística en la Universidad Complutense de Madrid.C.e.: sarmen01@ucm.es

Javier Ramos es estudiante del Doble Grado en Economía y Matemáticas y Estadística en la Universidad Complutense de Madrid.C.e.:jramos04@ucm.es

Ana Toyos es estudiante del Doctorado en Economía en la Universidad Complutense de Madrid. C. e.: anatoyos@ucm.es 


\section{INTRODUCTION}

Pre-industrial economies were characterized by three main features: a) a tendency to stagnation or a very low growth of per capita GDP over the very long run ${ }^{1}$; b) intense yearly fluctuations of the economic aggregates, especially the agricultural output ${ }^{2}$; and c) a high degree of uncertainty ${ }^{3}$. Bad and very bad harvests, particularly in the case of bread cereals, constituted the main determining factor of the great volatility of both agricultural product and GDP in pre-industrial Europe. It is not strange, then, that European and Spanish scholars have paid attention to agrarian crises and their demographic consequences since the $1960 \mathrm{~s}^{4}$.

The fundamental purpose of this paper lies in measuring the severity of wheat crises in eight farms ${ }^{5}$ during the $18^{\text {th }}$ century: four farms belonging to the Monastery of Guadalupe $^{6}$, one to the Cistercian Monastery of Santa María de Matallana ${ }^{7}$, another to the Cistercian Monastery of Medina de Rioseco ${ }^{8}$ and two estates ${ }^{9}$ located in the province of Córdoba ${ }^{10}$. We start from a very simple idea: the magnitude of agricultural disasters

1. Clark (2007: 1) holds that before 1800 , any short-term gains in income per capita through technological advancements were inevitably lost through population growth. ZANDEN (2009: 23943) and Malanima (2011:189) offer somewhat less pessimistic views on the evolution of GDP per capita in preindustrial Europe.

2. LABRousse (1962) stressed out the relevance of the economic fluctuations in the periods before the Industrial Revolution.

3. Uncertainty was particularly acute in the trading sphere (GRENIER, 1996: 421).

4. See, without any intention of exhaustivity, MEuvret $(1946,1965)$, Goubert $(1960,1965)$, Ponsot (1969), Anes (1970), Flinn (1974), Del PANTA and Livi-Bacci (1977), Pérez Moreda (2010), AlfaNi and Ó Gráda (2017), and Ó GrádA (2009).

5. Explotaciones agricolas in the Spanish original: "large-scale family farm", "business farm" or even "industrial farm" could be used to accurately translate this term. We have chosen "farm", in general, as a neutral term although we are well aware about the different sizes of the eight farms included in our sample.

6. El Rincón, La Burguilla, Madrigalejo and La Vega are located in the Valdepalacios unpopulated land areas (nowadays, the municipality of Logrosán), in Villar del Pedroso, Madrigalejo and Villar de Rena, respectively. The first three farms were located in the current province of Cáceres and the last one in the province of Badajoz.

7. Santa María de Matallana is located in the place of Matallana de Campos, near Villalba de los Alcores (province of Valladolid).

8. The Quintanajuar farm is located in the north of the province of Burgos. Specifically, in the region of Merindades, between the small towns of Cernégula and Masa.

9. Cortijo in the Spanish original: a country house with buildings, very typical in many parts of southern Spain; we have chosen the English term farmhouse.

10. We have not included in the sample the series of wheat yields from the reserve of the Monastery of Carracedo in León because the accounts of this farm have an important gap between 1757 and 
does not only depend on the decrease in yields or in harvests during the year of the disaster, but also on the agricultural results obtained in the period of time immediately before and after the sterile years. Hence, we first introduce a synthetic indicator that integrates the extent of the collapse in yields during the year of the disaster and, when required, the relative deficit of this variable during the previous and subsequent years. Then, we have tried to identify the most severe wheat crises together with the circumstances in which cereal crop failures reached a greater generalization and intensity.

Although this work is essentially quantitative, we have also attempted to find out the decisive causes of the lost harvests by using primary and secondary sources in the case of the farms belonging to the Monastery of Guadalupe.

The time frame of this research is limited due to the availability of annual data of wheat yields per seed or per hectare without gaps or practically without gaps. Our initial objective was to cover a long-time period, from the last third of the $17^{\text {th }}$ century to the end of the $18^{\text {th }}$ century. However, considerable gaps in the sources forced us to consider only the first three quarters of the $18^{\text {th }}$ century ${ }^{11}$.

This article is structured in four sections. In section 2 the sources used are presented and criticized, and the methodology employed is described; in section 3, the results on the evolution of the number, intensity and severity of wheat yields crises are presented and examined; in section 4, we identify and study the most severe cereal crises; and, finally, in section 5 the main conclusions of this work are summarized.

\section{SOURCES AND METHODOLOGY}

Usually studies on any agricultural crisis in modern Europe are mainly based on records about tithes and cereals prices. However, we will use an alternative source: wheat yields per seed or per hectare ${ }^{12}$ obtained from the accounts of two estates belonging to the Cathedral of Córdoba ${ }^{13}$ and six monastic farms in Extremadura and Castile. Since these

1767 (SAAVEDRA, 1987: 283). Neither those from the Nieva farms of the Monastery of El Parral and the Monastery of Hocina in Santa María de Rioseco because the series only cover the period 174067 or the interval 1685-1706, respectively (GARCÍA SANZ, 1985: 209; BRUMONT, 1985: 145).

11. Specifically, the series from the six monastic farms begin in 1699 and end in 1781, while those regarding the two Córdoba farms cover the period 1699-1799.

12. Morineau (1970) used numerous series of cereal yields in his study on French agriculture in the $18^{\text {th }}$ century with a different purpose: to determine whether or not an agricultural revolution took place in that country in the aforementioned century. 
ledgers were only intended for internal use, their information about harvests and seeds seems highly accurate. Nevertheless, these farms' ledgers present drawbacks and advantages for the objectives pursued by this work.

One of the main drawbacks is the low representativeness. As Aymard (1973: 476) pointed out, studies on farms based on yields per unit of area or seed only allow for general conclusions once a considerable number of case studies has been carried out. Unfortunately, the farms ledgers from the $17^{\text {th }}$ and $18^{\text {th }}$ centuries have not been preserved in sufficient numbers to enable the reconstitution of a series without gaps -or virtually without them- so as to meet such requirement. On the contrary, some evidence points out that, compared to normal years, the system of tithing was carried out differently in the years of crisis.

Anyhow, cereal farms' accounts are preferable to tithes data when it comes to studying the impact of agricultural disasters on peasant economies, especially since the mid$18^{\text {th }}$ century. The figures obtained from tithes tend to magnify the cereal disasters due to the fact that the aforementioned tithes were being paid with less rigor during periods of crisis (Llopis et al., 2018b). Also, unless a detailed study (based on the tazmias or "tithe files") is carried out on each single farm, tithes data show less severe yearly fluctuations than the actual quantities harvested by each direct grower, particularly in relatively large territories ${ }^{14}$. Thus, the evolution of yields per seed or per area of a farm appears to be a more accurate measurement of crop volatility -and therefore, of cereal crises in the different farms- than those focused on the trajectory of tithes.

Since this research is based mainly on monastic farm accounts, it needs to incorporate an assumption so that its main conclusions can go beyond the mere cases under study: the oscillations of the yields in these farms -belonging to regular ecclesiastical institutesclosely resembled those registered in the cereal farms located in their surrounding areas. Indeed, both monastic estates and ecclesiastical institutions included most of the time lands of superior average quality than the land of the majority of the grain farms. Also, those who exploited these higher quality lands -both their owners and the large tenants who were responsible for that task- had, in fact, more productive capital per unit area than

13. The yields of the Córdoba estates, expressed in hectoliters of wheat per hectare, a very unusual information in the primary sources of modern times, come from PonsoT (1986: 487-90). The Cathedral of Córdoba leased all its estates. Panguía had an area of 352 ha and La Rinconada had 673 ha. The latter was divided into two parts: Rinconada Alta and Rinconada Baja (Ponsot, 1982: 43133). The farms of Panguía and Rinconada Alta are part of the sample of eight cereal farms.

14. It is well known that crop volatility decreases as the territory under scrutiny expands. 
the average number of growers in the area ${ }^{15}$. That said, small landowners and tenants generally worked the land more carefully than wage earners in large and medium-sized farms. Therefore, it is likely that the use of more labor per hectare in modest peasant farms at least partially compensate for the use of poorer quality land and the lower endowment of productive capital. In sum, we believe that the risk is not excessive, assuming that the results of the large and small cereal farms did not substantially differ in years of short or very short harvests.

In any case, we are convinced that the approach to agricultural crises should be carried out by contrasting different types of sources. Therefore, we measure the crops disasters in a part of Extremadura looking at two different samples: the wheat yields in four farms of the Monastery of Guadalupe and the tercias reales (a tax equivalent to 2/9 of the tithe) collected in grain from Trujillo and its hinterlands ${ }^{16}$.

The main sources used are the ledgers from four monastic farms belonging to the Monastery of Guadalupe ${ }^{17}$; the cultivated land belonging to the Monastery of Santa María de Matallana ${ }^{18}$; the Quintanajuar farm - which belonged to the Monastery of Santa María de Rioseco ${ }^{19}$; as well as two estates owned by the Cathedral Chapter of Córdoba ${ }^{20}$. The ledgers provide detailed data on the volume of cereals sown and harvested each year, allowing us to calculate the annual yields per seed in all monastic farms, and per hectare in the two Córdoba estates ${ }^{21}$. These sources offered only ten unobserved entries on wheat

15. The latter can also be applied to the large tenants who exploited the estates belonging to the cathedral chapter of the Cathedral of Córdoba.

16. These included the tercias (thirds) of Cañamero, Zurita, Aldeanueva, Bercozana, Logrosán, Centenera, Acedera, Orellana la Vieja, Navalvillar de Pela, Orellananita, El Campo, Conquista de la Sierra (Zarza de la Conquista, as it was then known), Alcollarín, Herguijuela, Santa Cruz de la Sierra, Abertura, Escurial, Puerto de Santa Cruz, Valhondo, Búrdalo, Madrigalejo, Robledillo de Trujillo, Santa Ana, Ruanes, Plasenzuela, La Cumbre, Trujillo and Valdepalacios. In total, 28 population centers (Instrucción de un passagero para no errar un camino..., 1697: 242-44). From this point forward we will use "Trujillo and its hinterland" to name this region.

17. Account books of El Rincón farm, Archivo del Monasterio de Guadalupe (AMG), docket 143; accounts of La Burguilla farm, AMG, docket 141; accounts of Madrigalejo farm, AMG, docket 130; accounts of La Vega farm, AMG, docket 140.

18. Accounts from the Matallana monastery cereal farm, Archivo Histórico Nacional (AHN), Clero, books 16.262 and 16.263 .

19. Bread basket books of Quintanajuar farm at the Monastery of Santa María de Rioseco, AHN, Clero, books $1.331,1.408$ and 1.414 .

20. Panguía and Rinconada Alta (Ponsot, 1986: 487-90).

21. We have not conducted a study of the yields per area or per unit of barley and rye seed because we cannot assure that part of the crops of these cereals have never been used harvested in green. 
yields $^{22}$. We have estimated such gaps by considering the increases or decreases of crops at the farms of the Monastery of Guadalupe and the estates in Córdoba ${ }^{23}$.

The series of tercias reales from Trujillo and its hinterlands ${ }^{24}$ has only one unobserved record concerning the year 1735 . Tithed quantities depended on the sown area -which used to be proportional to the cultivated area ${ }^{25}$, on the output and on the degree of rigor in the tithe's payment. Hence, those quantities did not solely result from the harvest/seed ratio. Given that the tercias reales from Trujillo and its hinterland reflect the wheat production from a much larger area than the one from the farms of the Monastery of Guadalupe, then the former's volatility should have been lower than that registered by the yields in El Rincón, La Burguilla, Madrigalejo and La Vega. Consequently, it could be expected that the wheat crises in the farms of the Monastery of Guadalupe were of significantly greater magnitude than those in Trujillo and its hinterland. Although levels are not comparable, it is possible to contrast the trends towards a worsening or a moderation of agricultural disasters.

How are the yields' crises calculated and measured? We assume that a crisis was taking place in a given farm when the harvest/seed ratio dropped by more than $25 \%$ with respect to the mean of such ratio between 1700 and 1774 . We have excluded from the computation the ten highest values and the ten lowest, respectively. That is, the 75 -year truncated averages are our benchmark to determine and gauge the importance of a crisis. In order to identify and compute mortality crises, our initial purpose was to replicate Del Panta and Livi-Bacci's method, where a comparison is being carried out by using 11year truncated moving averages (1977: 401-46). In their analysis, they use 11-long truncated moving average. However, we had to abandon this plan when we observed, as shown in Figures 1-8, that the series of wheat yields of all the farms and estates have important level changes and, probably, relatively long cycles.

Accordingly, if we had applied Del Panta and Livi-Bacci's methodology, we would had underestimated the number and intensity of the crises in the periods of relatively low yields and we would had introduced a bias on the reverse direction in the periods of relatively high yields.

22. One in El Rincón, one in La Vega, four in Panguía and four in Rinconada Alta. The hojas de gracias allowed us to fill some of the gaps in the account books of the farms of the Monastery of Guadalupe ("Hojas de Gracias", AMG, docket 143).

23. We have not included more Córdoba estates in the sample of wheat farms because the number of unobserved records of wheat yields is significantly higher than in Panguía and Rinconada Alta.

24. "Hojas de Pan", AMG, docket 149; "Hojas de Pan", AHN, Clero, book 1.560.

25. There were some changes in farming systems, but they were infrequent. 
FIGURE 1

Wheat yields per unit of seed in E1 Rincón farm, 1699-1781

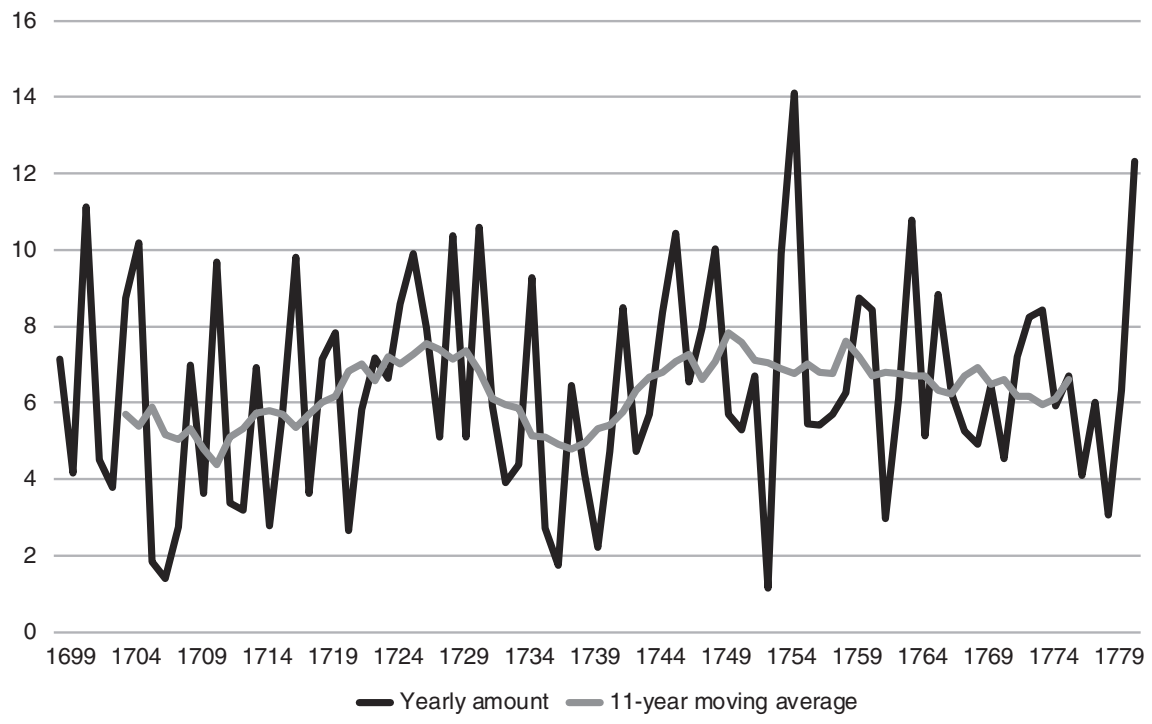

Source: El Rincón farm accounts, AMG, docket 143.

FIGURE 2

Wheat yields per unit of seed in La Burguilla farm, 1699-1781

16

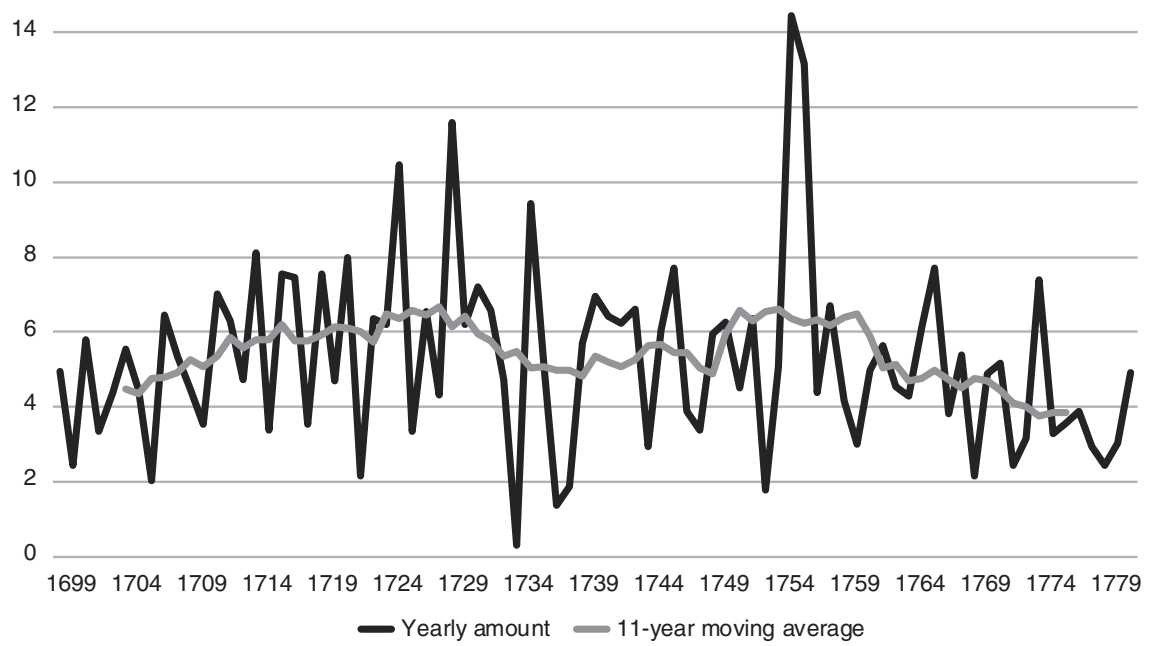

Source: La Burguilla farm accounts, AMG, docket 141. 
FIGURE 3

Wheat yields per unit of seed in Madrigalejo farm, 1699-1781

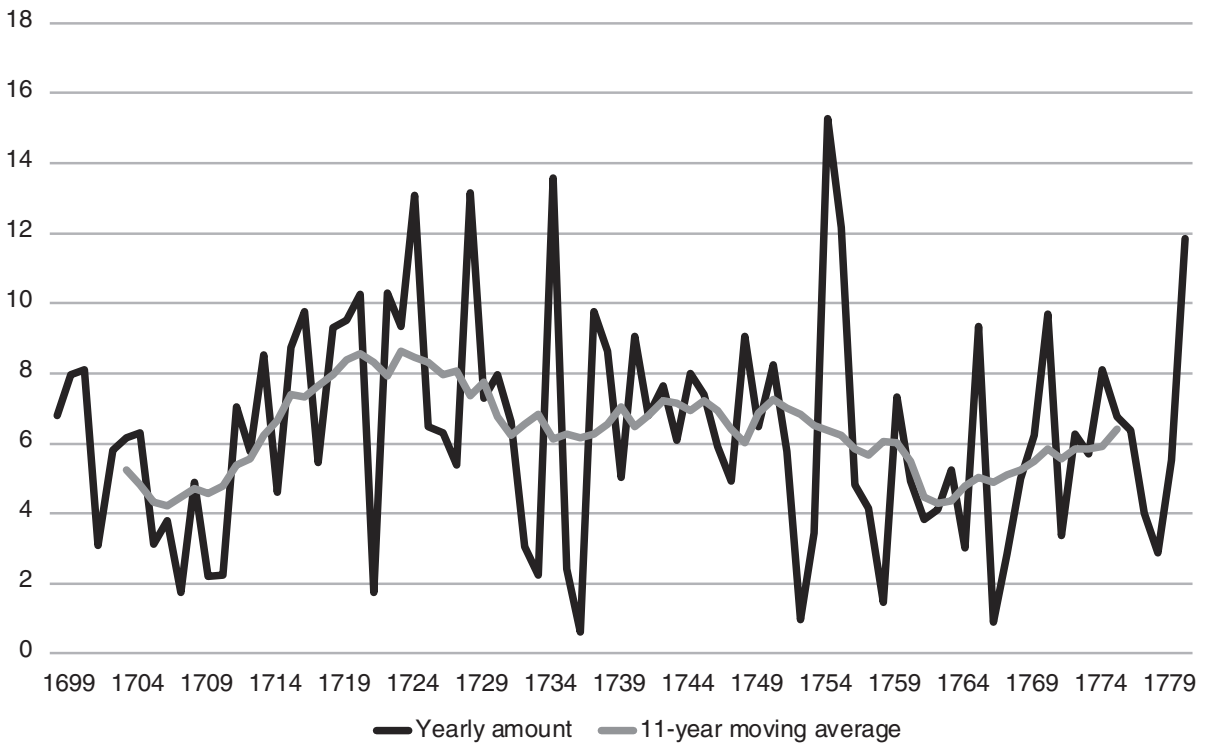

Source: Madrigalejo farm accounts, AMG, docket 130.

FIGURE 4

Wheat yields per unite of seed in La Vega farm, 1699-1781

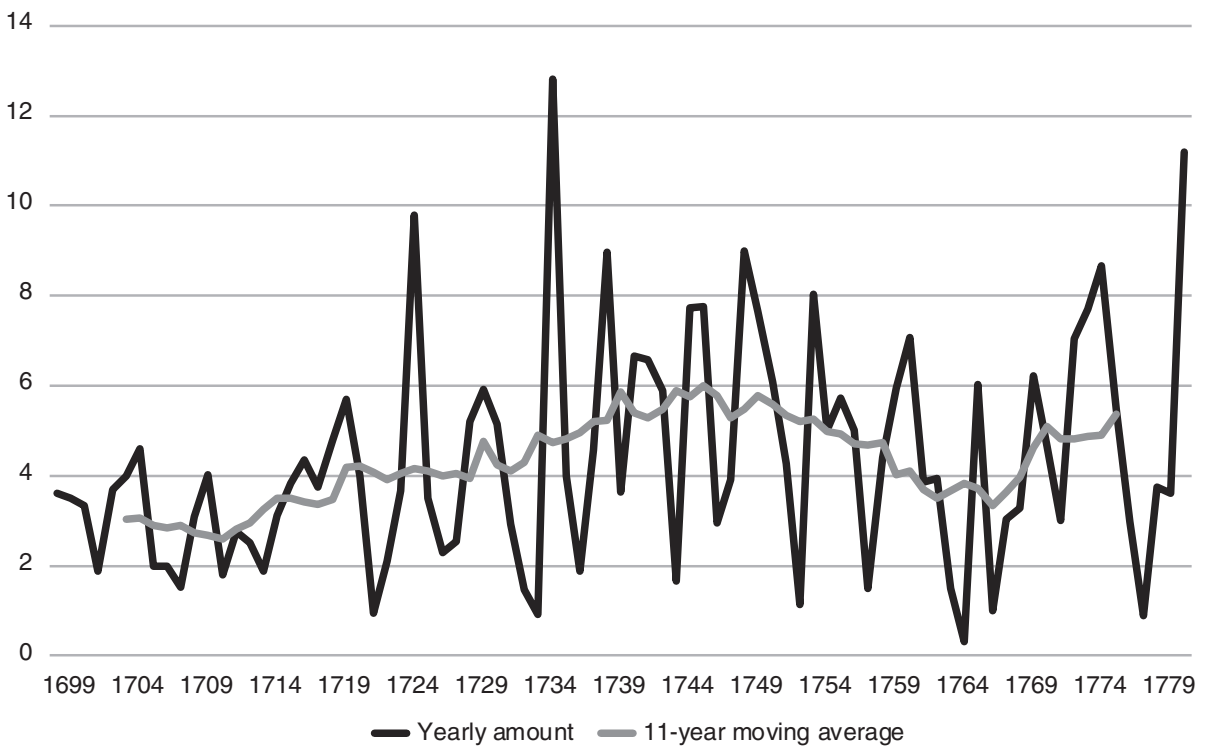

Source: La Vega farm accounts, AMG, docket 130. 
FIGURE 5

Wheat yields per unit of seed in Quintanajuar farm, 1699-1781

8

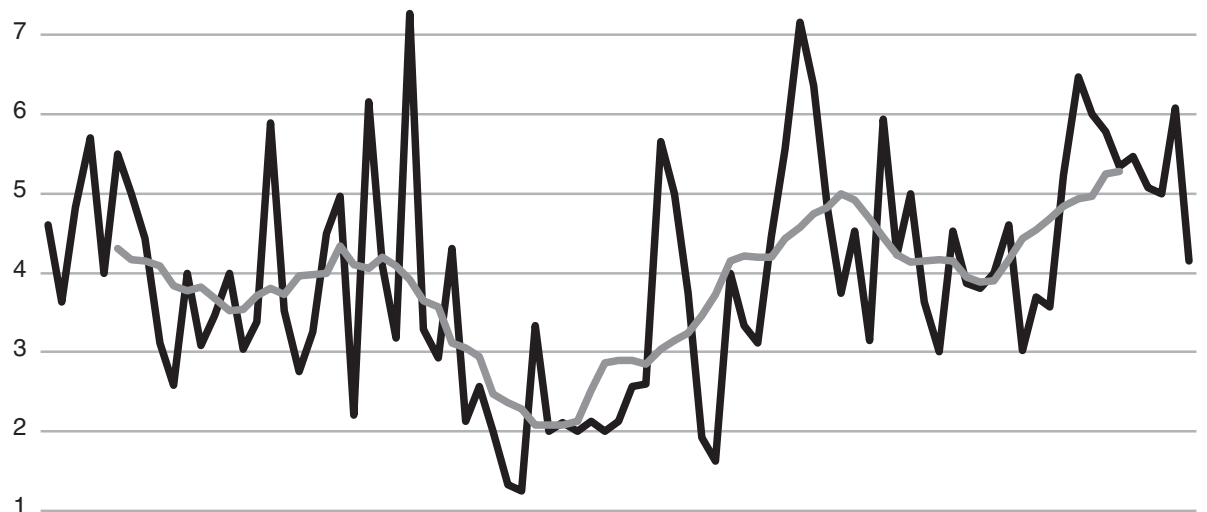

0

$1699170417091714171917241729173417391744 \quad 1749 \quad 1754 \quad 17591764176917741779$

- Yearly amount —11-year moving average

Source: Quintanajuar farm accounts at the Monastery of Santa María de Rioseco, AHN, Clero, books 1.331, 1.408 and 1.414 .

FIGURE 6

Wheat yields per unit of seed in the cereal farms of Matallana, 1699-1781 12

10

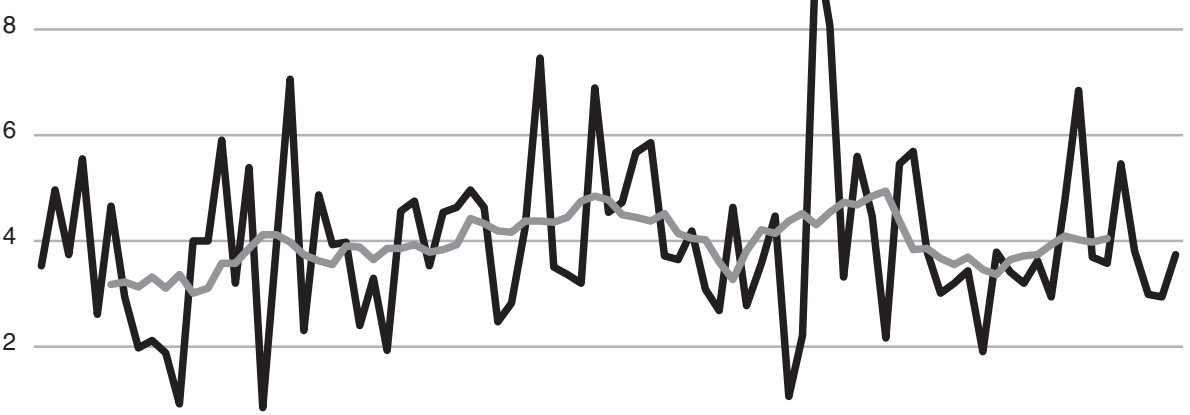

0

$16991704 \quad 17091714 \quad 17191724 \quad 1729 \quad 1734 \quad 1739 \quad 1744 \quad 1749 \quad 1754 \quad 1759 \quad 1764 \quad 1769 \quad 1774 \quad 1779$

- Yearly amount 11-year moving average

Source: Monastery of Matallana cereal farm accounts, AHN, Clero, books 16.262-16.263. 


\section{FIGURE 7}

Wheat yields per unit are in Panguía farmhouse, 1699-1799 (in hectoliters/hectare) 14

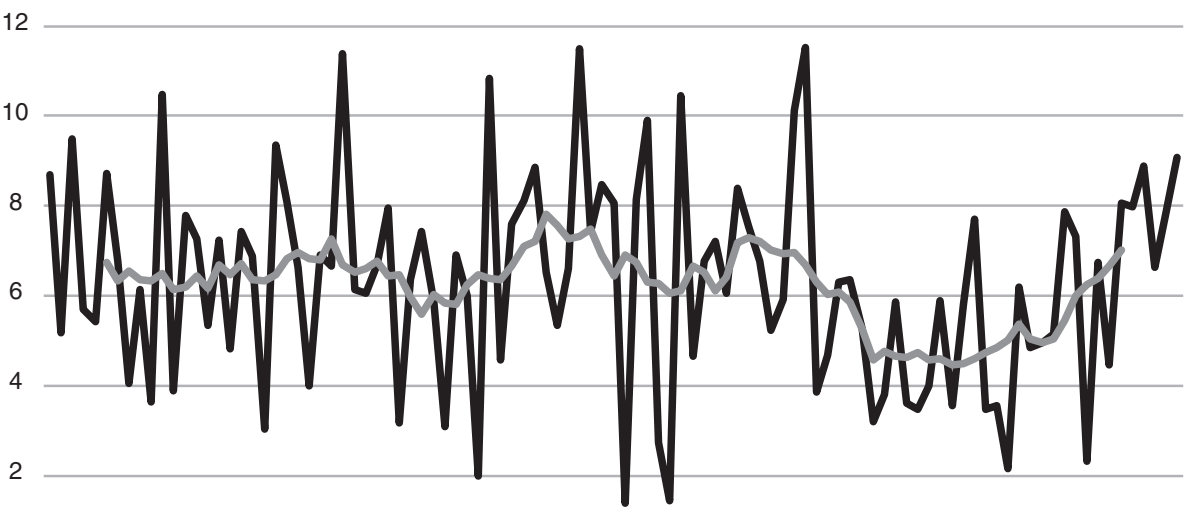

0

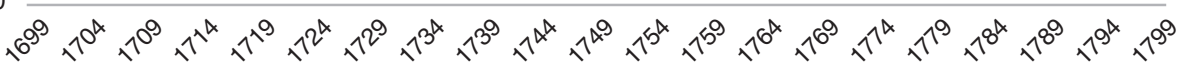
- Yearly amount —11-year moving average

Source: Ponsot (1986: 487-90).

FIGURE 8

Wheat yields per unit area in Rinconada farmhouse, 1699-1799 (in hectoliters/hectare)

12

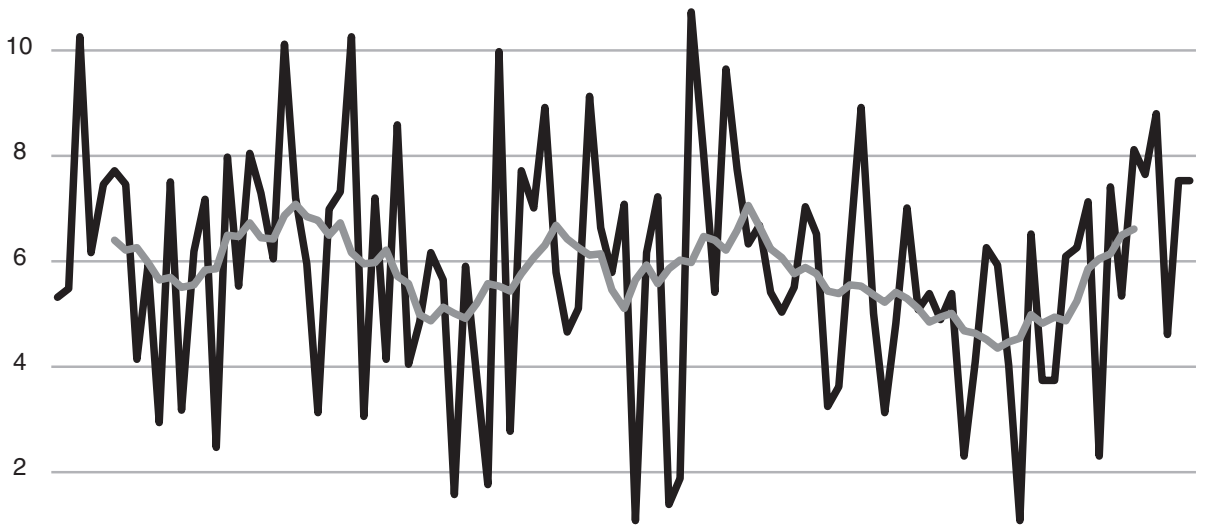

0

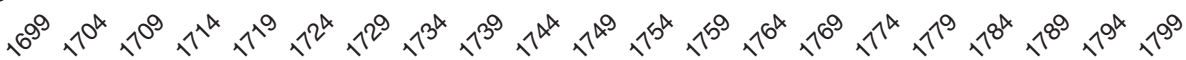
- Yearly amount -11 -year moving average

Source: Ponsot (1986: 487-90). 
We consider a year to be of poor harvests when the yields per seed -or per hectare-dropped relative to the corresponding truncated average from $25 \%$ to $50 \%$. Subsequently, a year of very poor harvests occurs when the fall ranged from $50 \%$ to $75 \%$; and a year of dreadful harvests takes place when the decline exceeded $75 \%$.

However, we intend to go beyond and track the evolution in the scale of the crises in the long run. For such purpose, we have elaborated a synthetic indicator, for periods of twenty-five years, that integrates the two main elements of this phenomenon: the crises' frequency and intensity. It is calculated by adding up, as absolute values, the yields' deviations (expressed as a percentage) with respect to the corresponding truncated mean during each crisis for the periods $1700-24,1725-49$ and $1750-74^{26}$.

The severity of a grain disaster does not depend only on the extent of the collapse of the yields in the year of the crisis: it is also linked to the relative level of the harvests during the three years immediately preceding and following the calamity. This way, we consider that a deficit in yields before and after a crisis occurs when its average drops by over $12.5 \%$ relative to the corresponding truncated average. We consider that deficit as moderate when the fall is ranged between $12.5 \%$ and $25 \%$; a large deficit when the reduction ranges between $25 \%$ and $50 \%$, and an enormous deficit when it exceeds $50 \%$. Once this deviation threshold is established, we determine and measure the deficits in yields for the years right before and after the crisis.

We also develop synthetic indicators -structured in periods of twenty-five years- for wheat yields' deficits during the three years preceding or following the crises. They are calculated by adding up the yield average deviations in the three years preceding or following the crises in relation to the corresponding truncated average, provided that those have a negative sign and exceed $12.5 \%$ in all the years of wheat disasters during each of the three quarters of the century under study.

Finally, we elaborate -although with an exploratory and provisional character-a synthetic index of the yields' crises severity, integrating three elements: the drop of the harvest/seed ratio in the year of the disaster in relation to the truncated average, the yields' deficit -when it is appropriate- in the three years preceding a crisis, and the yields' deficit -when appropriate- in the three years following a crisis. The values of the first item range from 2 to 6 points: 2 points when the deviation is situated between $25 \%$ and $50 \%, 4$ points when it varies between $50 \%$ and $75 \%$, and 6 points when it exceeds $75 \%$. The values of

26. This methodology has been inspired by FLINN (1974: 285-318) to construct an indicator that measures the frequency and intensity of mortality crises. 
the second and the third element range between 0 and 4.5 points: 0 points when a surplus is recorded, or the deficit does not reach $12.5 \%$ in relation to the truncated average; 1.5 when the deficit ranges between $12.5 \%$ and $25 \%$; 3 when it is situated between $25 \%$ and $50 \%$; and 4.5 when it exceeds $50 \%$. Thus, the synthetic index may fluctuate between a minimum of 2 points and a maximum of 15 . In the first case, there are no deficits in the three years preceding or following the crisis year and the decline of the yields in the latter varies between $25 \%$ and $50 \%$ with respect to the truncated average. The second case would place us in the worst of all worlds: the deficits in the three years preceding or following the crisis year would exceed $50 \%$, and the decline of the yields would exceed $75 \%$ in the latter. None of the farms witnessed a crisis of such magnitude during the first three quarters of the $18^{\text {th }}$ century.

Once these calculations have been carried out for all the grains' disasters in each one of the farms, the synthetic indicator on the severity of crises -for 25-year periods- is obtained by adding up the synthetic indicators of all episodes of disasters in harvests registered at the different intervals during that quarter of a century which are included in the study. This latter indicator will allow for a better approximation to the long-term evolution of the actual magnitude of the crises in wheat yields in the farms under study for this research.

We shall now examine in detail the crises in wheat yields as follows: first, we begin by analysing the long-term evolution of the index which exclusively measures deviations in respect to the harvest/seed ratio's truncated average in the sterile years; secondly, we will consider how the frequency and intensity of crises have behaved in the course of the first three quarters of the $18^{\text {th }}$ century; thirdly, we delve the long-term evolution of yields' deficits in the three years preceding and in the three following each crisis; fourthly, the long-term path of the synthetic indicator that considers the yields' crisis magnitude and their own deficits during the three years preceding and following those crises shall be evaluated; fifthly, the major yields crises and the periods when those were more intense and more widespread are going to be reviewed separately, and, sixthly, we will compare the magnitude and trajectories of the yields crises in the farms belonging to the Monastery of Guadalupe and to the tercias reales from Trujillo and its hinterland.

In sum, the main methodological innovation of our paper consists in designing a synthetic index about the severity of the yields crisis which takes into account not just the magnitude of the decline but also what happened to the harvests in the previous and subsequent years. 


\section{THE CRISES OF WHEAT YIELDS IN THE $18^{\mathrm{TH}}$ CENTURY}

Between 1700 and 1774 the annual average wheat yields per unit of seed were 6.28 in El Rincón, 5.30 in La Burgilla, 6.17 in Madrigalejo, 4.03 in La Vega, 3.75 in Quintanajuar and 3.87 in Matallana. The harvest/seed ratio was significantly higher in the farms of the Monastery of Guadalupe than those belonging to the Cistercian monasteries of Medina de Rioseco ${ }^{27}$ and Matallana. However, land productivity also depended on the cultivation system and on the greater or lesser concentration of seeds. In fact, differences in land productivity between the Monastery of Guadalupe farms and those from the two aforementioned Castilian monasteries were significantly lower than what it could be inferred from the yields per unit of seed: the three-field harvesting system ${ }^{28}$ was employed in the first three farms of Guadalupe, while the two-field system was probably chosen instead of the second ones. From 1700 to 1774 the average annual yields per hectare in the estates of Panguía and Rinconada Alta were 6.45 and 6.04 hectoliters of wheat, respectively.

From 1650 to 1760, annual average yields of the wheat seed in various Sicilian farms belonging to the Jesuits ranged from 7 to 10, clearly above those registered in monastic farms of Extremadura and Castile. However, the wheat harvest/seed ratio at that time was higher in Sicily than in most parts of other Italian territories (Aymard, 1973: 485-86, 492).

\subsection{The synthetic indexes of the yields' crises in the long-term}

Table 1 shows the synthetic index of wheat yields crises -over 25-year periods-in the eight farms and estates included in our sample ${ }^{29}$.

Between 1700 and 1774, the yields' crises had a greater impact on the farms of Extremadura than in the remaining farms, and they were of a relatively greater magnitude in the Córdoba estates than in the Castilian monastic ones. However, the regional sam-

27. Brumont carried out a study on the Quintanajuar farmhouse between 1625 and 1835 . He examined the yields per unit of wheat and barley seed but didn't publish their annual series: those are reflected only in graphics (BRUMONT, 1979: 396-99). We have therefore used information collected from primary sources in order to build the wheat yields series of the Quintanajuar farmhouse.

28. Thus, for example, each of the work sheets of the Madrigalejo farmhouse should have -as proposed by one of Guadalupe monastery stewards at the end of the $17^{\text {th }}$ century- an extension of 32040 bushels (Instrucción de un passagero para no errar..., 1697: 282).

29. Only in the case of the two Córdoba estates have we been able to extend the data series to the end of the $18^{\text {th }}$ century. 
ples are too meagre to be able to assign these results to the entire territories of Extremadura, Western Andalusia and Old Castile.

TABLE 1

Synthetic index of the wheat yields' crises in eight farms and estates, 1700-99 (\%)

\begin{tabular}{|c|c|c|c|c|c|c|c|c|}
\hline Period & El Rincón & La Burguilla & Madrigalejo & La Vega & Quintanajuar & Matallana & Panguía & Rinconada Alta \\
\hline $1700-24$ & 598.9 & 315.5 & 434.1 & 517.8 & 98.7 & 462.8 & 237.1 & 238.4 \\
\hline $1725-49$ & 296.3 & 378.2 & 265.1 & 386.9 & 689.6 & 94.1 & 201.2 & 350.4 \\
\hline $1750-74$ & 162.2 & 291.9 & 544.2 & 390.1 & 0.0 & 240.0 & 401.6 & 362.9 \\
\hline $1775-99$ & - & - & - & - & - & - & 425.3 & 348.6 \\
\hline $1700-74$ & $1,057.5$ & 985.6 & $1,243.4$ & $1,294.8$ & 788.3 & 796.8 & 839.9 & 951.8 \\
\hline Period & \multicolumn{2}{|c|}{$\begin{array}{c}\text { Four farms of the Monastery } \\
\text { of Guadalupe (average) }\end{array}$} & \multicolumn{2}{|c|}{$\begin{array}{c}\text { Two Córdoba } \\
\text { estates (average) }\end{array}$} & \multicolumn{3}{|c|}{$\begin{array}{l}\text { All farms and estates, with the } \\
\text { exception of Quintanajuar (average) }\end{array}$} & $\begin{array}{c}\text { All farms and } \\
\text { estates (average) }\end{array}$ \\
\hline $1700-24$ & \multicolumn{2}{|c|}{466.6} & \multicolumn{2}{|c|}{237.8} & \multicolumn{3}{|c|}{400.7} & 362.9 \\
\hline $1725-49$ & \multicolumn{2}{|c|}{331.6} & \multicolumn{2}{|c|}{275.8} & \multicolumn{3}{|c|}{281.8} & 332.7 \\
\hline $1750-74$ & \multicolumn{2}{|c|}{347.1} & \multicolumn{2}{|c|}{382.3} & \multicolumn{3}{|c|}{341.8} & 299.1 \\
\hline $1775-99$ & \multicolumn{2}{|c|}{ - } & \multicolumn{2}{|c|}{387.0} & \multicolumn{3}{|c|}{ - } & - \\
\hline $1700-74$ & \multicolumn{2}{|c|}{$1,145.4$} & \multicolumn{2}{|c|}{895.8} & \multicolumn{3}{|c|}{$1,024.3$} & 994.8 \\
\hline
\end{tabular}

Sources: see notes $17-20$.

The trajectory of this index was quite uneven in the different farms, but particularly unusual in the Quintanajuar farm: crises here were of little or no magnitude during the first and the third quarters of the $18^{\text {th }}$ century, while they became very dramatic during the interval 1725-49. The reason for such a contrast lies in the fact that the average yields were too low in the decades of 1730 and $1740^{30}$. This result matches the relatively high intensity and frequency of the mortality crises that took place in the second half of the 1730s and 1740s in Castile and León (Llopis et al., 2015: 69-82).

If we now focus on all four farms of the Monastery of Guadalupe, the most outstanding feature is the moderation of the crises after 1725: the index dropped by $28.9 \%$ between 1700-24 and 1725-49, and by $25.6 \%$ between 1700-24 and 1750-74. Disasters in Matallana were more intense during the first quarter of the $18^{\text {th }}$ century than in the two following quarters. Regarding the two estates in Córdoba, the most outstanding increase of the synthetic index occurred in the second half of the $18^{\text {th }}$ century ( $88.7 \%$ over the first half). This higher virulence of the wheat yields' crises in the countryside of Córdoba is well in line with the natality crises' rebound observed in Andalusia over the last five decades of the $18^{\text {th }}$ century (Llopis \& Sebastián, 2019).

30. The annual average yields of the wheat seed in Quintanajuar were 4.01 in $1700-29,2.66$ in $1730-49$ and 4.54 in 1750-74. So, the fall in yields between the first and the second period was $33.7 \%$. 
When analysing the synthetic index that integrates those eight cereal farms, data suggest a moderate decrease in the magnitude of the crises between the first and the second quarter and also between the second and the third quarter of the $18^{\text {th }}$ century: $8.3 \%$ and $10.1 \%$, respectively. The decline between $1700-24$ and $1750-74$ was of the order of $17.6 \%$. If we exclude Quintanajuar from this aggregate, the decline between the first and the third quarter of the century was a bit smaller $(-14.7 \%)$. However, the main feature of the sample rate indicator -which includes seven farm holdings- is the considerable decrease of the impact of the crises during the second quarter of the $18^{\text {th }}$ century $(29.7 \%)$. As a contrast it bounced back to $21.3 \%$ in the third quarter.

\subsection{Frequency and intensity of crises}

Tables 2 and 3 display the average frequency and intensity of the crises into 25-year periods.

TABLE 2

Average number of years in-between wheat yields' crises, 1700-99

\begin{tabular}{|c|c|c|c|c|c|c|c|c|}
\hline Period & El Rincón & La Burguilla & Madrigalejo & La Vega & Quintanajuar & Matallana & Panguía & Rinconada Alta \\
\hline $1700-24$ & 2.1 & 3.6 & 3.1 & 2.5 & 8.3 & 2.8 & 4.2 & 5.0 \\
\hline $1725-49$ & 4.2 & 3.6 & 6.3 & 3.1 & 1.7 & 8.3 & 6.3 & 3.6 \\
\hline $1750-74$ & 8.3 & 4.2 & 2.5 & 4.2 & - & 5.0 & 3.1 & 4.2 \\
\hline 1775-99 & - & - & - & - & - & - & 2.8 & 3.6 \\
\hline $1700-74$ & 3.6 & 3.8 & 3.4 & 3.1 & 4.2 & 4.4 & 4.2 & 4.2 \\
\hline Period & \multicolumn{2}{|c|}{$\begin{array}{l}\text { Four farms of the Monastery } \\
\text { of Guadalupe (average) }\end{array}$} & $\begin{array}{l}\text { y Two Córd } \\
\text { estates (av }\end{array}$ & $\begin{array}{l}\text { loba } \\
\text { erage) }\end{array}$ & \multicolumn{3}{|c|}{$\begin{array}{l}\text { All farms and estates, with the } \\
\text { exception of Quintanajuar (average) }\end{array}$} & $\begin{array}{c}\text { All farms and } \\
\text { estates (average) }\end{array}$ \\
\hline $1700-24$ & \multicolumn{2}{|c|}{2.7} & 4.5 & & \multicolumn{3}{|c|}{3.1} & 3.3 \\
\hline $1725-49$ & \multicolumn{2}{|c|}{4.0} & 4.5 & & \multicolumn{3}{|c|}{4.5} & 3.7 \\
\hline $1750-74$ & \multicolumn{2}{|c|}{4.0} & 3.6 & & \multicolumn{3}{|c|}{4.0} & 4.5 \\
\hline 1775-99 & \multicolumn{2}{|c|}{-} & 3.1 & & \multicolumn{3}{|c|}{-} & - \\
\hline $1700-74$ & \multicolumn{2}{|c|}{3.4} & 4.2 & & \multicolumn{3}{|c|}{3.8} & 3.8 \\
\hline $1700-99$ & \multicolumn{2}{|c|}{-} & 3.8 & & \multicolumn{3}{|c|}{-} & - \\
\hline
\end{tabular}

Sources: see Table 1 .

During the period 1700-74 one crisis occurred every 3.4 years in the Guadalupe farms, a greater frequency than those at Córdoba (one every 4.2 years) and the Castilian monasteries' farms (one every 4.3 ). 
TABLE 3

Average intensity of wheat yields' crises in eight farms and estates, 1700-74 (\%)

\begin{tabular}{|c|c|c|c|c|c|c|c|c|}
\hline Period & El Rincón & La Burguilla & Madrigalejo & La Vega & Quintanajuar & Matallana & Panguía & Rinconada Alta \\
\hline $1700-24$ & 49.9 & 45.1 & 54.3 & 51.8 & 32.9 & 51.4 & 39.5 & 47.7 \\
\hline $1725-49$ & 49.4 & 54.0 & 66.3 & 48.4 & 46.0 & 31.4 & 50.3 & 50.1 \\
\hline $1750-74$ & 54.1 & 48.7 & 54.4 & 65.0 & - & 48.0 & 50.2 & 60.5 \\
\hline $1775-99$ & - & - & - & - & - & - & 47.3 & 49.8 \\
\hline $1700-74$ & 50.4 & 49.3 & 56.5 & 54.0 & 43.8 & 46.9 & 46.7 & 52.9 \\
\hline $1700-99$ & - & - & - & - & - & - & 46.9 & 52.0 \\
\hline Period & \multicolumn{2}{|c|}{$\begin{array}{c}\text { Four farms of the Monastery } \\
\text { of Guadalupe (average) }\end{array}$} & \multicolumn{2}{|c|}{$\begin{array}{c}\text { Two Córdoba } \\
\text { estates (average) }\end{array}$} & \multicolumn{3}{|c|}{$\begin{array}{l}\text { All farms and estates, with the } \\
\text { exception of Quintanajuar (average) }\end{array}$} & $\begin{array}{c}\text { All farms and } \\
\text { estates (average) }\end{array}$ \\
\hline $1700-24$ & \multicolumn{2}{|c|}{50.4} & \multicolumn{2}{|c|}{43.2} & \multicolumn{3}{|c|}{49.2} & 48.4 \\
\hline $1725-49$ & \multicolumn{2}{|c|}{53.1} & \multicolumn{2}{|c|}{50.2} & \multicolumn{3}{|c|}{50.6} & 49.3 \\
\hline $1750-74$ & \multicolumn{2}{|c|}{55.5} & \multicolumn{2}{|c|}{54.6} & \multicolumn{3}{|c|}{54.4} & 54.4 \\
\hline $1775-99$ & \multicolumn{2}{|c|}{-} & \multicolumn{2}{|c|}{48.4} & \multicolumn{3}{|c|}{-} & - \\
\hline $1700-74$ & \multicolumn{2}{|c|}{52.7} & \multicolumn{2}{|c|}{49.8} & \multicolumn{3}{|c|}{51.2} & 50.4 \\
\hline 1700-99 & \multicolumn{2}{|c|}{-} & 49.3 & & \multicolumn{3}{|c|}{-} & - \\
\hline
\end{tabular}

Sources: see Table 1.

From the beginning of the second quarter of the $18^{\text {th }}$ century, crises tended to become less frequent in all farms: one every 3.3 years in 1700-24, one every 3.7 years in 1725 49 , and one every 4.5 years in 1750-74. Yet, some farms were exempt from such a drop: in the two Córdoba estates, one crisis occurred every 4.5 years during the first half of the $18^{\text {th }}$ century, and every 3.3 years during the second one. The maximum frequency took place at Quintanajuar (one crisis every 1.7 years), whereas the minimum one did in Matallana between 1725 and 1749 .

As shown in Table 3, the average intensity of the crises in yields between 1700 and 1774 exceeded $50 \%$ in the four farms of Guadalupe, reached almost $50 \%$ in the two Córdoba estates, and slightly exceeded $45 \%$ in the farmlands of the Castilian Cistercian monasteries. The deepest crises occurred in Extremadura.

The average intensity of the crises in the eight farms slightly increased by $2.8 \%$ during the second quarter of the $18^{\text {th }}$ century and grew a little bit more in the third one (7.5\%). The rise was $10.6 \%$ between $1700-24$ and $1750-74$. The group of four farms of the Monastery of Guadalupe and the two Córdoba estates followed such pattern of increasing magnitude. In Matallana, the disasters peaked in the first quarter of the century and registered their lowest level during the second one. As for Quintanajuar, frequency and intensity reached their peak between 1725 and 1749 . 
In sum, the Extremadura's cereal farms underwent the most severe yields' crises of the sample. Despite a slight upturn, there was a moderate decline of the synthetic index. This fall was achieved by a reduction in the frequency of agricultural disasters since the second quarter of the $18^{\text {th }}$ century.

\subsection{The deficits of yields before and after the crises}

In Table 4 we include, in 25-year periods, the aggregate deficits of the wheat yields during the three-year periods prior to crises.

\section{TABLE 4}

Aggregate deficits of wheat yields in eight farms and estates during the three-year periods prior to crises, 1700-99 (\%)

\begin{tabular}{|c|c|c|c|c|c|c|c|c|}
\hline Period & El Rincón & La Burguilla & Madrigalejo & La Vega & Quintanajuar & Matallana & Panguía & Rinconada Alta \\
\hline $1700-24$ & 97.8 & 17.0 & 140.3 & 167.4 & 0.0 & 122.6 & 0.0 & 0.0 \\
\hline $1725-49$ & 89.8 & 0.0 & 0.0 & 20.9 & 467.6 & 0.0 & 17.3 & 79.8 \\
\hline $1750-74$ & 0.0 & 45.0 & 115.0 & 57.9 & 0.0 & 38.5 & 47.9 & 38.9 \\
\hline $1775-99$ & - & - & - & - & - & - & 168.6 & 117.9 \\
\hline $1700-74$ & 187.7 & 62.0 & 255.3 & 246.2 & 467.6 & 161.1 & 65.2 & 118.7 \\
\hline Period & \multicolumn{2}{|c|}{$\begin{array}{c}\text { Four farms of the Monastery } \\
\text { of Guadalupe (average) }\end{array}$} & \multicolumn{2}{|c|}{$\begin{array}{c}\text { Two Córdoba } \\
\text { estates (average) }\end{array}$} & \multicolumn{3}{|c|}{$\begin{array}{l}\text { All farms and estates, with the } \\
\text { exception of Quintanajuar (average) }\end{array}$} & $\begin{array}{c}\text { All farms and } \\
\text { estates (average) }\end{array}$ \\
\hline $1700-24$ & \multicolumn{2}{|c|}{105.6} & \multicolumn{2}{|c|}{0.0} & \multicolumn{3}{|c|}{77.9} & 68.1 \\
\hline $1725-49$ & \multicolumn{2}{|c|}{27.7} & \multicolumn{2}{|c|}{48.6} & \multicolumn{3}{|c|}{29.7} & 84.4 \\
\hline 1750-74 & \multicolumn{2}{|c|}{54.5} & \multicolumn{2}{|c|}{43.4} & \multicolumn{3}{|c|}{49.0} & 42.9 \\
\hline 1775-99 & \multicolumn{2}{|c|}{-} & \multicolumn{2}{|c|}{71.6} & \multicolumn{3}{|c|}{-} & - \\
\hline 1700-74 & \multicolumn{2}{|c|}{187.8} & \multicolumn{2}{|c|}{92.0} & \multicolumn{3}{|c|}{156.6} & 195.5 \\
\hline
\end{tabular}

Sources: see Table 1 .

From 1700 to 1774 the aggregate deficits during the three-year periods before the crisis rose in three of the four farms of the Monastery of Guadalupe (El Rincón, Madrigalejo, La Vega, and Quintanajuar); over the same time period, the minima for such variable were registered both in La Burgilla and in Córdoba estates.

As for the temporal evolution, our deficit for the eight wheat farms increased by $23.9 \%$ between the first and the second quarter of the $18^{\text {th }}$ century and dropped abruptly (49.2\%) between 1725-49 and 1750-74. If we exclude Quintanajuar, the trajectory has a different outcome: a drop between the first and the second quarter of the century, reaching a minimum in 1725-49. 
In the four farms of the Monastery of Guadalupe, the aggregate deficits peaked in the first quarter of the $18^{\text {th }}$ century, reaching a minimum in the second one. The decline between $1700-24$ and $1750-74$ was $48.4 \%$. With respect to the two Córdoba estates, the most outstanding events were: 1) a worsening of the deficits during the second half of the century compared to the first half; and 2) their exceptionally high level during the last quarter of the century. Quintanajuar is, once again, the most atypical farm of the sample: there were no deficits in 1700-24 and 1750-74, but the variable reached a very high value in 1725-49. Finally, in Matallana deficits were registered a significant moderation since the second quarter of the century; up to the point that the deficit disappeared between 1725 and 1749 .

In short, during the third quarter of the $18^{\text {th }}$ century the decline of the deficits of the yields in the three years preceding the disasters was deeper than that from the crises' synthetic index (see Tables 1 and 4).

In Tables 5 and 6 we have reflected both the frequency and the average intensity of yields' deficits during the three-year periods prior to a crisis.

TABLE 5

Average number of years elapsed between a deficit of wheat yields in the three-year period preceding a crisis and the following one, 1700-99

\begin{tabular}{|c|c|c|c|c|c|c|c|c|}
\hline Period & El Rincón & La Burguilla & Madrigalejo & La Vega & Quintanajuar & Matallana & Panguía & Rinconada Alta \\
\hline $1700-24$ & 8.3 & 25.0 & 6.3 & 4.2 & - & 6.3 & - & - \\
\hline $1725-49$ & 8.3 & - & - & 25.0 & 2.1 & - & 25.0 & 8.3 \\
\hline $1750-74$ & - & 12.5 & 5.0 & 12.5 & - & 12.5 & 12.5 & 12.5 \\
\hline $1775-99$ & - & - & - & - & - & - & 4.2 & 6.3 \\
\hline $1700-74$ & 12.5 & 25.0 & 8.3 & 8.3 & 6.3 & 12.5 & 25.0 & 15.0 \\
\hline $1700-99$ & - & - & - & - & - & - & & \\
\hline Period & \multicolumn{2}{|c|}{$\begin{array}{c}\text { Four farms of the Monastery } \\
\text { of Guadalupe (average) }\end{array}$} & $\begin{array}{l}\text { Two Cór } \\
\text { estates (a) }\end{array}$ & $\begin{array}{l}\text { oba } \\
\text { erage) }\end{array}$ & \multicolumn{3}{|c|}{$\begin{array}{c}\text { All farms and estates, with the } \\
\text { exception of Quintanajuar (average) }\end{array}$} & $\begin{array}{c}\text { All farms and } \\
\text { estates (average) }\end{array}$ \\
\hline $1700-24$ & \multicolumn{2}{|c|}{7.1} & - & & \multicolumn{3}{|c|}{9.7} & 11.1 \\
\hline $1725-49$ & \multicolumn{2}{|c|}{25.0} & 12.5 & & \multicolumn{3}{|c|}{21.9} & 10.0 \\
\hline $1750-74$ & \multicolumn{2}{|c|}{11.1} & 12.5 & & \multicolumn{3}{|c|}{11.7} & 13.3 \\
\hline $1775-99$ & \multicolumn{2}{|c|}{-} & 5.0 & & \multicolumn{3}{|c|}{-} & - \\
\hline $1700-74$ & \multicolumn{2}{|c|}{11.1} & 18.8 & & \multicolumn{3}{|c|}{12.8} & 11.3 \\
\hline
\end{tabular}

Sources: see Table 1 .

In the first three quarters of the $18^{\text {th }}$ century, the lowest frequency of deficits in yields during the three-years preceding a crisis was registered in the Córdoba estates: an average of 
18.8 years elapsed between crises. Such outbreaks, however, became very frequent (one every five years) at the Andalusian cereal farms during the last quarter of the $18^{\text {th }}$ century.

\section{TABLE 6}

Average intensity of the aggregate deficits in wheat yields during the three-year period prior to crises in eight farms and estates 1700-99 (\%)

\begin{tabular}{|c|c|c|c|c|c|c|c|c|}
\hline Period & El Rincón & La Burguilla & Madrigalejo & La Vega & Quintanajuar & Matallana & Panguía & Rinconada Alta \\
\hline $1700-24$ & 32.6 & 17.0 & 35.1 & 27.9 & - & 30.7 & - & - \\
\hline $1725-49$ & 29.9 & - & - & 20.9 & 39.0 & - & 17.3 & 26.6 \\
\hline $1750-74$ & - & 22.5 & 23.0 & 29.0 & - & 19.2 & 24.0 & 19.4 \\
\hline 1775-99 & - & - & - & - & - & - & 28.1 & 29.5 \\
\hline $1700-74$ & 31.3 & 20.7 & 28.4 & 27.4 & 39.0 & 26.9 & 21.7 & 23.7 \\
\hline Period & \multicolumn{2}{|c|}{$\begin{array}{c}\text { Four farms of the Monastery } \\
\text { of Guadalupe (average) }\end{array}$} & \multicolumn{2}{|c|}{$\begin{array}{c}\text { Two Córdoba } \\
\text { estates (average) }\end{array}$} & \multicolumn{3}{|c|}{$\begin{array}{l}\text { All farms and estates, with the } \\
\text { exception of Quintanajuar (average) }\end{array}$} & $\begin{array}{c}\text { All farms and } \\
\text { estates (average) }\end{array}$ \\
\hline $1700-24$ & \multicolumn{2}{|c|}{30.2} & \multicolumn{2}{|l|}{-} & \multicolumn{3}{|c|}{30.3} & 30.3 \\
\hline $1725-49$ & \multicolumn{2}{|c|}{27.7} & \multicolumn{2}{|c|}{24.3} & \multicolumn{3}{|c|}{26.0} & 33.8 \\
\hline 1750-74 & \multicolumn{2}{|c|}{24.2} & \multicolumn{2}{|c|}{21.7} & \multicolumn{3}{|c|}{22.9} & 22.9 \\
\hline 1775-99 & \multicolumn{2}{|c|}{ - } & \multicolumn{2}{|c|}{28.6} & \multicolumn{3}{|c|}{ - } & - \\
\hline $1700-74$ & \multicolumn{2}{|c|}{27.8} & \multicolumn{2}{|c|}{23.0} & \multicolumn{3}{|c|}{26.7} & 29.5 \\
\hline
\end{tabular}

Sources: see Table 1 .

Between 1700 and 1774, in the three-year period prior to a crisis, one deficit of yields occurred, on average, every 11.1 years in the group of farms of the Monastery of Guadalupe; in the case of the two Castilian Cistercian farms, the frequency was one deficit every 8.3 years. Poor harvests in the periods immediately preceding the crises were more frequent in the Castilian cereal farms than in those of Extremadura and far more frequent than in the Córdoba estates.

Table 5 reveals that the deficits preceding the crises were less frequent in the eight farms during the third quarter of the $18^{\text {th }}$ century than during the two previous ones. When excluding Quintanajuar, the longest average interval of years between deficits is found in the second quarter of the $18^{\text {th }}$ century. Both in the group of farms of the Monastery of Guadalupe and in Matallana, the highest frequency took place between 1700 and 1724, and the lowest between 1725 and 1749. In Quintanajuar, all pre-crises' deficits (12) were concentrated during the second quarter of the century.

From 1700 to 1774, the average intensity of the yields' deficits in the three-year periods prior to the crisis was very similar among the group of farms of the Monastery of 
Guadalupe and the Castilian Cistercian farms. Such an intensity was, in turn, significantly higher than in the aggregate of the two Córdoba estates.

Table 6 shows a notable moderation of the average magnitude in the deficits in yields of the whole sample during the third quarter of the $18^{\text {th }}$ century. The decline was of the order of $24.4 \%$ between $1700-24$ and $1750-74$, and $32.2 \%$ between $1725-49$ and $1750-$ 74. Excluding Quintanajuar, the reduction between the first and the third quarter of the $18^{\text {th }}$ century amounted to $24.4 \%$ and to $11.9 \%$ between the second and the third quarters

The average intensity of deficits in yields during the three years before each crisis in the group of farms belonging to the Monastery of Guadalupe decreased in a moderate but steady way during the three first quarters of the $18^{\text {th }}$ century. In this regard, the most remarkable phenomena affecting the two Córdoba estates involved, on the one hand, was the absence of deficits in the period 1700-24 and, on the other hand, the worsening of their scale in the second half of the $18^{\text {th }}$ century. Both in Matallana and Quintanajuar such deficits moderated or disappeared from 1725 or 1750 .

\section{TABLE 7}

Aggregate deficits of wheat yields in the eight farms and estates in the three-year periods after crises, $1700-99(\%)$

\begin{tabular}{|c|c|c|c|c|c|c|c|c|}
\hline Period & El Rincón & La Burguilla & Madrigalejo & La Vega & Quintanajuar & Matallana & Panguía & Rinconada Alta \\
\hline $1700-24$ & 133.0 & 15.0 & 164.0 & 205.3 & 0.0 & 156.0 & 0.0 & 12.7 \\
\hline $1725-49$ & 125.0 & 0.0 & 0.0 & 0.0 & 459.8 & 0.0 & 23.1 & 56.8 \\
\hline $1750-74$ & 0.0 & 56.6 & 125.2 & 55.8 & 0.0 & 21.6 & 79.2 & 18.6 \\
\hline $1775-99$ & - & - & - & - & - & - & 170.3 & 60.4 \\
\hline $1700-74$ & 258.0 & 71.6 & 289.2 & 261.0 & 459.8 & 177.6 & 102.3 & 88.1 \\
\hline Period & \multicolumn{2}{|c|}{$\begin{array}{c}\text { Four farms of the Monastery } \\
\text { of Guadalupe (average) }\end{array}$} & \multicolumn{2}{|c|}{$\begin{array}{c}\text { Two Córdoba } \\
\text { estates (average) } \\
\end{array}$} & \multicolumn{3}{|c|}{$\begin{array}{l}\text { All farms and estates, with the } \\
\text { exception of Quintanajuar (average) }\end{array}$} & $\begin{array}{c}\text { All farms and } \\
\text { estates (average) }\end{array}$ \\
\hline $1700-24$ & \multicolumn{2}{|c|}{129.3} & \multicolumn{2}{|c|}{6.4} & \multicolumn{3}{|c|}{98.0} & 85.7 \\
\hline $1725-49$ & \multicolumn{2}{|c|}{31.3} & \multicolumn{2}{|c|}{40.0} & \multicolumn{3}{|c|}{29.3} & 83.1 \\
\hline $1750-74$ & \multicolumn{2}{|c|}{59.4} & \multicolumn{2}{|c|}{48.9} & \multicolumn{3}{|c|}{51.0} & 44.6 \\
\hline $1775-99$ & \multicolumn{2}{|c|}{ - } & \multicolumn{2}{|c|}{115.4} & \multicolumn{3}{|c|}{ - } & - \\
\hline $1700-74$ & \multicolumn{2}{|c|}{220.0} & \multicolumn{2}{|c|}{95.2} & \multicolumn{3}{|c|}{178.3} & 213.5 \\
\hline
\end{tabular}

Sources: see Table 1.

To sum up, the frequency and intensity of the yields' deficits in our sample during the three-year periods before crises tended to evolve in the same direction: both features -frequency and intensity- helped to overcome the wheat disasters generally in less adverse 
conditions after 1750 . However, this improvement owed more to the moderation of intensity than to the decrease of frequency.

Having examined the episodes of difficulty prior to the crises, we must now address the magnitude of the problems in the years immediately after such crises (Table 7).

In the three first quarters of the $18^{\text {th }}$ century, the aggregate deficits in yields during postcrises periods were lower in the two Córdoba estates and in La Burguilla; in contrast, the highest ones were registered in the remaining farms of the Monastery of Guadalupe and, most particularly, in Quintanajuar.

Since the second quarter of the $18^{\text {th }}$ century, the eight farms' indicator reflects a significant moderation of deficits in post-crises: a fall of -48\% between 1700-24 and 175074. Excluding Quintanajuar, the decline moves ahead into the 1725-49 period, it also happens with the group of four farms belonging to the Monastery of Guadalupe and Monastery and Matallana. Once again, Quintanajuar and the two Córdoba estates differed from the general trend, where the aggregate deficits in the post-crises increased during the $18^{\text {th }}$ century: 3.5 times greater in 1750-99 than in 1700-49. At Quintanajuar, on the other hand, the value was 0 in the first and the third quarter of the century but it reached a very high level in the second.

TABLE 8

Average number of years elapsed between a deficit of wheat yields and the following in the three-year period after a crisis

\begin{tabular}{|c|c|c|c|c|c|c|c|c|}
\hline Period & El Rincón & La Burguilla & Madrigalejo & La Vega & Quintanajuar & Matallana & Panguía & Rinconada Alta \\
\hline $1700-24$ & 5.0 & 25.0 & 6.3 & 4.2 & - & 5.0 & - & 25.0 \\
\hline $1725-49$ & 5.0 & - & - & - & 2.3 & - & 25.0 & 12.5 \\
\hline $1750-74$ & - & 8.3 & 5.0 & 12.5 & - & 25.0 & 8.3 & 25.0 \\
\hline 1775-99 & - & - & - & - & - & - & 4.2 & 12.5 \\
\hline $1700-74$ & 7.5 & 18.8 & 8.3 & 9.4 & 6.8 & 12.5 & 18.8 & 18.8 \\
\hline Period & \multicolumn{2}{|c|}{$\begin{array}{c}\text { Four farms of the Monastery } \\
\text { of Guadalupe (average) }\end{array}$} & $\begin{array}{l}\text { ywo Córc } \\
\text { estates (av }\end{array}$ & $\begin{array}{l}\text { loba } \\
\text { erage) }\end{array}$ & \multicolumn{3}{|c|}{$\begin{array}{l}\text { All farms and estates, with the } \\
\text { exception of Quintanajuar (average) }\end{array}$} & $\begin{array}{c}\text { All farms and } \\
\text { estates (average) }\end{array}$ \\
\hline $1700-24$ & \multicolumn{2}{|c|}{6.3} & 50.0 & & \multicolumn{3}{|c|}{8.0} & 9.1 \\
\hline $1725-49$ & \multicolumn{2}{|c|}{20.0} & 16.7 & & \multicolumn{3}{|c|}{21.9} & 10.5 \\
\hline $1750-74$ & \multicolumn{2}{|c|}{10.0} & 12.5 & & \multicolumn{3}{|c|}{11.7} & 13.0 \\
\hline 1775-99 & \multicolumn{2}{|c|}{ - } & 6.3 & & \multicolumn{3}{|c|}{ - } & - \\
\hline $1700-74$ & \multicolumn{2}{|c|}{9.7} & 18.8 & & \multicolumn{3}{|c|}{11.7} & 10.7 \\
\hline
\end{tabular}

Sources: see Table 1. 
In other words, the crises of the yields tended to be less extreme in the first three quarters of the $18^{\text {th }}$ century, but their aggregate deficits moderate in a far more conclusive way over the three-year periods before and after the shocks.

Tables 8 and 9 gather the evolution of both the average frequency and intensity of the yields' deficits in post-crises periods.

TABLE 9

Average intensity of wheat yields' deficits

in the three-year periods following the crisis, 1700-99 (\%)

\begin{tabular}{|c|c|c|c|c|c|c|c|c|}
\hline Period & El Rincón & La Burguilla & Madrigalejo & La Vega & Quintanajuar & Matallana & Panguía & Rinconada Alta \\
\hline $1700-24$ & 26.6 & 15.0 & 41.0 & 34.2 & - & 31.2 & - & 12.7 \\
\hline $1725-49$ & 25.0 & - & - & - & 41.8 & - & 23.1 & 28.4 \\
\hline $1750-74$ & - & 18.9 & 25.0 & 27.9 & - & 21.6 & 16.4 & 18.6 \\
\hline $1775-99$ & - & - & - & - & - & - & 28.4 & 30.2 \\
\hline $1700-74$ & 25.8 & 17.9 & 32.1 & 32.6 & 41.8 & 29.6 & 25.6 & 22.0 \\
\hline Period & \multicolumn{2}{|c|}{$\begin{array}{c}\text { Four farms of the Monastery } \\
\text { of Guadalupe (average) }\end{array}$} & $\begin{array}{l}\text { Two Córo } \\
\text { estates (av }\end{array}$ & $\begin{array}{l}\text { oba } \\
\text { erage) }\end{array}$ & \multicolumn{3}{|c|}{$\begin{array}{c}\text { All farms and estates, with the } \\
\text { exception of Quintanajuar (average) }\end{array}$} & $\begin{array}{c}\text { All farms and } \\
\text { estates (average) }\end{array}$ \\
\hline $1700-24$ & \multicolumn{2}{|c|}{32.3} & 12.7 & & \multicolumn{3}{|c|}{31.2} & 31.2 \\
\hline $1725-49$ & \multicolumn{2}{|c|}{25.0} & 26.6 & & \multicolumn{3}{|c|}{25.6} & 35.0 \\
\hline $1750-74$ & \multicolumn{2}{|c|}{23.8} & 24.5 & & \multicolumn{3}{|c|}{23.8} & 23.8 \\
\hline $1775-99$ & \multicolumn{2}{|c|}{ - } & 28.8 & & \multicolumn{3}{|c|}{ - } & - \\
\hline $1700-74$ & \multicolumn{2}{|c|}{28.4} & 23.8 & & \multicolumn{3}{|c|}{27.7} & 30.5 \\
\hline
\end{tabular}

Sources: see Table 1 .

Between 1700 and 1774 the lowest frequency of the yield deficits in the post-crises years was registered in La Burgilla and the two Córdoba estates ${ }^{31}$; in contrast, the highest was recorded in Madrigalejo, El Rincón and Quintanajuar. During the first three quarters of the $18^{\text {th }}$ century, the average of the yield deficits in the three-year periods following the disasters was 4 in the Córdoba estates, 7.75 in the Extremadura, and 8.5 in the Castilian farms.

In the eight farms, the average number of years elapsed between yield deficits in postcrises periods tended to increase: 9.1 years in 1700-24, 10.5 in 1725-49 and 13.3 in 1750-

31. Between 1700 and $\mathbf{1 7 2 4}$, in the two Córdoba estates we have only found the occurrence of a yields' deficit once during the three-year period following crises. Thus, half a deficit in twenty-five years is equivalent to one deficit every fifty years. This is the reason for such figure-apparently absurd- to appear in the first entry from the third column on the second half of Table 8. 
74. The trend of these figures changes if we exclude Quintanajuar: thus, the lowest frequency of this phenomenon is found in the second quarter of the $18^{\text {th }}$ century, just like in the group of farms of the Monastery of Guadalupe and Matallana. Once again atypical behaviour can be found again in Quintanajuar and in the two Córdoba estates. In the former, no deficit was recorded during the post-crises years in 1700-24 and 1750-74, although not less than eleven occurred in 1725-49. In the two Andalusian estates this phenomenon happened more frequently in the second half of the century.

Between 1700 and 1774 the average intensity of deficits in yields in the post-crises crisis years reached their peak in the Castilian farms, and their lowest ones in the Córdoba estates. The average intensity of the post-crisis deficits increased by $12.2 \%$ between $1700-$ 24 and 1725-49 in the whole sample but underwent a decrease of $32 \%$ between 1725 49 and 1750-74. Excluding Quintanajuar, this variable also declines between the first and the second quarter of the $18^{\text {th }}$ century, with more intensive drops concentrating in 172549. The same happened with the aggregate of the four farms belonging to the Monastery of Guadalupe. The two Córdoba estates did not follow this general pattern: on the one hand, the lowest average intensity of such deficits took place in the interval 1700-24 and, on the other hand, this variable was higher during the second half of the century. Quintanajuar was quite particular in the extent that there were no post-crisis deficits in 170024 and 1750-74. Furthermore, the average intensity of those deficits reached the absolute maximum of the eight farms in the second quarter of the $18^{\text {th }}$ century.

To sum up, the post-crises deficits in yields became, in general, less frequent and less intense with their changes having a greater impact on their virulence than on their frequency. After 1750, the deficits in yields in the three-year periods before and after the crises reached a significantly lower scale than during the first half of the $18^{\text {th }}$ century. Therefore, they contributed to mitigate the sequels of grain disasters.

\subsection{A new synthetic indicator of the severity of crises}

The synthetic index of the severity of the crises in the different farms and estates is shown in Table 10. We intend to bring together a single indicator the extent of the disasters that occurred during pre-crises, crises and post-crises of wheat yields.

Table 10 reveals that the severity of the 1700-74 crises was lower in the two Córdoba estates than in most of the remaining farms of our sample. The maximum values of this index were recorded in Madrigalejo, Quintanajuar and La Vega. 
TABLE 10

Synthetic index of severity of the wheat yields' crises in eight farms and estates, 1700-99 (in units)

\begin{tabular}{|c|c|c|c|c|c|c|c|c|}
\hline Period & El Rincón & La Burguilla & Madrigalejo & La Vega & Quintanajuar & Matallana & Panguía & Rinconada Alta \\
\hline $1700-24$ & 60 & 23 & 52.5 & 76.5 & 6 & 55.5 & 14 & 15.5 \\
\hline $1725-49$ & 39 & 22 & 18.0 & 27.5 & 126 & 6 & 17 & 33.5 \\
\hline $1750-74$ & 12 & 25.5 & 60.0 & 36.5 & 0 & 18.5 & 38.5 & 26.5 \\
\hline $1775-99$ & - & - & - & 一 & - & - & 53.5 & 40.0 \\
\hline $1700-74$ & 111 & 70.5 & 130.5 & 140.5 & 132 & 80 & 69.5 & 75.5 \\
\hline Period & \multicolumn{2}{|c|}{$\begin{array}{c}\text { Four farms of the Monastery } \\
\text { of Guadalupe (average) }\end{array}$} & \multicolumn{2}{|c|}{$\begin{array}{c}\text { Two Córdoba } \\
\text { estates (average) }\end{array}$} & \multicolumn{3}{|c|}{$\begin{array}{c}\text { All farms and estates, with the } \\
\text { exception of Quintanajuar (average) }\end{array}$} & $\begin{array}{c}\text { All farms and } \\
\text { estates (average) }\end{array}$ \\
\hline $1700-24$ & \multicolumn{2}{|c|}{53.0} & \multicolumn{2}{|c|}{14.8} & \multicolumn{3}{|c|}{42.4} & 37.9 \\
\hline $1725-49$ & \multicolumn{2}{|c|}{26.6} & \multicolumn{2}{|c|}{25.3} & \multicolumn{3}{|c|}{23.3} & 36.1 \\
\hline $1750-74$ & \multicolumn{2}{|c|}{33.5} & \multicolumn{2}{|c|}{32.5} & \multicolumn{3}{|c|}{31.1} & 27.2 \\
\hline $1775-99$ & \multicolumn{2}{|c|}{-} & \multicolumn{2}{|c|}{46.8} & \multicolumn{3}{|c|}{ - } & - \\
\hline $1700-74$ & \multicolumn{2}{|c|}{113.1} & 72.5 & & \multicolumn{3}{|c|}{96.8} & 101.2 \\
\hline
\end{tabular}

Sources: see Table 1; and our own calculations.

This indicator of maximum aggregation points to a mild mitigation of the crises between the first and second quarter of the $18^{\text {th }}$ century, as well as to a more forceful moderation of those crises between the second and the third quarters. Indeed, the index itself decreases by $4.6 \%$ between $1700-24$ and $1725-49$, and $24.7 \%$ between $1725-49$ and $1750-74$. Between the first and the third quarter of the $18^{\text {th }}$ century, the decline was $-28.2 \%$. Excluding Quintanajuar, the balance between $1700-24$ and $1750-74$ is practically the same. However, the index collapses between the first and the second quarter of the $18^{\text {th }}$ century (a reduction of $45.1 \%$ ) and it picks up between the second and the third quarter (a rise of $33.4 \%$ ). Contrary to what happened to most farms, the severity of the crises tended to accentuate in the Córdoba estates during the course of the $18^{\text {th }}$ century. In the group of farms belonging to the Monastery of Guadalupe, this indicator was reduced almost by a half between the first and the second quarter of the $18^{\text {th }}$ century and subsequently increased, although it remained far from its initial level. The index behaviour in Matallana is similar to what happened with the group of farms of the Monastery of Guadalupe, but its decline between 1700-24 and 1725-49 was far more abrupt. Lastly, Quintanajuar reappears as an atypical case: either there were no crises or they had a minimum effect during the first and third quarter of the $18^{\text {th }}$ century. However, crises and deficits before and after them were many and quite large in the second quarter.

In short, the severity of the crisis in wheat yields tend to decrease since the end of the first or the second quarter of the $18^{\text {th }}$ century, although that is not the case of the Cór- 
doba estates. The mitigation of such episodes is due more to the moderation of the deficits in the three-year periods before and after the crises than to the smaller drops in yields during the years of bad, very bad or dreadful harvests in relation with the corresponding truncated averages.

\subsection{The greatest crises and the worst economic situations}

We have above studied the medium and long-term evolution of the crises in wheat yields in different farms. We will now turn to analyze the most important cereal disasters and the circumstances around them.

In $1706,1708,1737$ and 1753 there were bad, very bad or dreadful harvests in seven of the eight cereal farms in the sample. The average intensities of the crises in yields in those years were 50.0, 52.6, 68.1 and $73.1 \%$, respectively (see Table A of the Statistical Appendix). In addition to the cruel cold during the late years of the first decade of the $18^{\text {th }}$ century, Guadalquivir River overflowed fourteen times as it passed through Seville between December 1707 and June 1708 (Alberola, 2014: 188). It is likely that the torrential rains contributed to the disastrous harvests in the southwestern quadrant of the Iberian Peninsula. In the Chapter meeting held on August 14 of that same year, the Monastery of Guadalupe agreed to borrow up to 12,000 ducats in order to buy between 4,000 and 5,000 fanegas (a fanega being 1,57 bushels) of wheat, barley and rye ${ }^{32}$. Barns were nearly empty due to the bad harvest of 1708 and of previous years. Both winter and spring of 1753 were extremely dry across Extremadura and it happened after several years of scarce rainfall that region and in other Spanish areas (Alberola, 2009: 71, 78-9).

Six of the eight farms in the sample experienced crises of wheat yields in 1722,1734 and 1767 . Their average intensities were $55.3 \%, 65.3 \%$ and $54.3 \%$, respectively. An extended period of drought was experienced in Castile between 1720 and 1724 (Alberola, 2009: 72). On $6^{\text {th }}$ of April 1734, the Virgin of Guadalupe was carried in procession to bring the long-awaited water to the fields ${ }^{33}$.

Extreme weather conditions prevailed in the second half of the 1760s: the persistent drought also coexisted with violent and repeated rainfall, floods and flash floods, with harsh

32. Book of Chapter Acts of the Monastery of Guadalupe, 1671-1702, AHN, Clero, codex 103 B, f. 166 r.

33. Book of Chapter Acts of the Monastery of Guadalupe, 1671-1802, AHN, Clero, codex 103-B, ff. $242 r-243 r$. 
winters, unusual springtime, short and humid summers, hailstorms and frosts that, in addition to making worse the harm already inflicted upon Spanish agriculture, caused significant material damage and human losses (Alberola, 2014: 1999, our translation).

In sum, the drought, often accompanied by other climatic abnormalities, was present in almost all the worst crisis in wheat yields affecting the farms analyzed in this research.

The decade of 1706-15 and the interval 1733-40 were the periods when a greater number of yields crisis were concentrated. They proved to be crises of great significance as well (see Table A of the Statistical Appendix) ${ }^{34}$. In both periods there was at least one crisis in each of the years. During the first of these two periods, bad, very bad or dreadful harvests were recorded in 1706 and 1708, five in 1710 and 1714 and four in 1707. During this decade, El Rincón (7), La Vega (7) and Madrigalejo (5) were the farms with the highest number of cereal disasters.

During the period 1733-40, 1733, 1734 and 1737 were the most critical years. In 1733, there were yield crises in 7 out of the 8 farms and states, in 1734 in 6 and in 1737 in 7 . The average decrease of yields was $68.1 \%$ in $1737,65.3 \%$ in 1734 and 49.0 in 1733 .

\subsection{Crises of yields and crises of tithes}

In the following paragraphs, we will compare the wheat yields' crises in the Monastery of Guadalupe farms with those in the harvests of wheat across the region surrounding Trujillo over the period 1725-74. The synthetic index of the crises in wheat production inside of Trujillo and its hinterland, their frequency and average intensity have been displayed on Table 11.

TABLE 11

Synthetic index, frequency and intensity average of the wheat production crises in the Trujillo and its hinterland, 1725-49

\begin{tabular}{lccc}
\hline Period & Synthetic index(\%) & Frequency (average number of years in-between crises) & Average intensity(\%) \\
\hline $1725-49$ & 227.4 & 5.0 & 45.5 \\
$1750-74$ & 268.3 & 3.6 & 38.3 \\
\hline
\end{tabular}

Source: “Hojas de Pan”, AMG, docket 149; “Hojas de Pan”, AHN, Clero, book 1560.

34. A considerable number of yields crises also took place during the periods 1746-64 and 176572. 
From 1725-49 to 1750-74 the synthetic index of the crises of the tercias reales increased by $18.0 \%$ and the yields crises' index in the aggregate of the four farms of the Monastery of Guadalupe only increased by $4.7 \%$. Between the second and third quarter of the $18^{\text {th }}$ century, the frequency of poor cereal results increased in the Trujillo and its hinterland but barely varied in the houses of the Monastery of Guadalupe. From 1725-49 to 175074 the average intensity of the crises in the tercias reales declined by $15.8 \%$ and the yields' average intensity in the group of farms of the Monastery of Guadalupe increased by $4.5 \%$. The frequency effect outweighed the intensity effect: the synthetic index of the tercias reales therefore increased more than the yields' index in the farms belonging to the Guadalupe.

The synthetic index showing the severity of crises in the "Royal Thirds" of Trujillo and its hinterland -which includes what happened in the three-year long periods before and after the sterile years- rose from 17 in 1725-49 to 23.5 in 1750-74. Therefore, it increased by $38.2 \%$. The same indicator for the 4 farms of the Monastery of Guadalupe rose by $25.8 \%$ between the second and third quarter of the $18^{\text {th }}$ century. This differential could be explained by the fact that the cereal crises of the 1760 s were more intense in the lands of the Trujillo region (Llopis, 1989: 276). A rebound in the magnitude of the wheat setbacks in Extremadura during the third quarter of the $18^{\text {th }}$ century is reflected in both decimal records and yields.

\section{CONCLUSIONS}

The methodological novelty involved in the development of a synthetic index of the severity of crises must be emphasized. It does not only quantify the magnitude of the collapse in yields or in production in the years of short, very short or dreadful harvests, but also measures and computes, when it is appropriate, the deficits recorded in these variables in the three years immediately preceding and following the cereal disasters. Thus, information is provided by this index about the adverse situation in which some crises had to be faced. And, whenever it was relevant, also about the aggravation of problems due to the shortness of the harvests in the years following the agricultural failures. Grain stored by most peasants was nearly always insufficient to face a severe production crisis. But there is little doubt that the accumulated reserves, partly dependent on previous harvests, could sometimes help producers to keep afloat. They were not forced to cut down family bread consumption nor to expand their financial imbalance, thus increasing the indebtedness of their lands. Mediocre or poor harvests after a crisis could, in turn, accentuate malnutrition and the financial shortages of many peasant families. In short, we will better understand and will more effectively measure the scope of agricultural crisis if we expand the range and analyze what has happened in previous and subsequent years. 
We consider that our index of the severity of crises has three relevant advantages: methodological simplicity, low level of data demands and capacity -with one digit- to bring us closer to the scale of a cereal disaster or -with some digits- to do so to the trajectory of its scale in different periods. In addition, the methodology applied to the analyses of yields could be extended -with the pertinent adjustments required in each case- to the study of natality, mortality, marriage or prices crises. The specific index used here, as we have already pointed out, has a provisional character. We are aware that could be improved through the incorporation of the crop surpluses recorded in the years immediately before and after the crises.

According to the synthetic index of the severity of crises in the eight farms, the cereal disasters reached their greatest magnitude in the first quarter of the $18^{\text {th }}$ century. The analysis of each of the elements included in this synthetic index shows that, since the second quarter of the $18^{\text {th }}$ century, the lower severity of the crises was due more to the mitigation of the deficits in the yields in the years immediately before and after the sterility years than to the moderation of the decreases of the yields in the years of short or very short harvests.

The farms of the Guadalupe Monastery were those registering a larger number of years of very bad or dreadful harvests. The years of most widespread cereal disasters were: 1706, 1708, 1737 and 1753. A more or less prolonged drought, often accompanied by other climatic anomalies, did not fail the appointment with almost all episodes of lost harvests.

The periods of worst harvests were particularly $1706-15$ and also 1733-40. Thus, the individualized study of the crises and their various conjunctures confirm that the first fifteen years of the $18^{\text {th }}$ century were the period of time in which the most generalized and severe agricultural setbacks were concentrated.

The examination of the wheat yields in four farms of the Monastery of Guadalupe and the scrutiny of the tercias reales of the same grain in Trujillo and its hinterlands suggest that cereal crises increased in Extremadura during the third quarter of the $18^{\text {th }}$ century.

It would perhaps be desirable to water down the implications of the results obtained in our essay. First of all, because the size of the sample is too small. Secondly, because nearly all the farms were located in two of the regions with the worst agrarian balance in $18^{\text {th }}$ century Spain: Extremadura and Andalusia. Lastly, although the cereal sector is an important and essential landmark, it was not the best tool to examine or, at least, to grasp the extent of the agrarian transformations in most Spanish regions over the second half of the $18^{\text {th }}$ century. As it also happened in Portugal, the main changes and advances af- 
fecting $18^{\text {th }}$ century agriculture in most regions and not just in the periphery, were not only restricted to the production of grains: the diversification of crops and an increased relative importance of the non-cereal activities constituted the most relevant novelties (Serrão, 2007, 2017; Llopis \& Sebastián, 2019). The appreciable reduction of both ordinary and catastrophic mortality in the second half of the $18^{\text {th }}$ century in various regions, including inner Spain, provides an important evidence to sustain the hypothesis that there was some agrarian progress in this period and territory (Llopis et al., 2018a). To conclude, it is likely that the moderation of the agricultural crises in most of the Spanish regions during the second half of the $18^{\text {th }}$ century was greater than what it is suggested by our indicator of their severity.

\section{ACKNOLEDGMENTS}

We would like to thank the two anonymous referees of Historia Agraria for their helpful comments and suggestions. We would also like to thank Antonio Gómez Mendoza and David González Agudo for all their help with the translation of this article and their thoughtful suggestions.

\section{REFERENCES}

Alberola, A. (2009). "No puedo sujetar la pluma de puro frío, porque son extremados los yelos": El clima en la España de los reinados de Felipe V y Fernando VI a través de la correspondencia de algunos ilustrados. Investigaciones Geográficas, (49), 65-88. Alberola, A. (2014). Los cambios climáticos: La Pequeña Edad del Hielo en España. Madrid: Cátedra.

AlfANI, G. \& Ó GrÁDA, C. (2017). Famine in European History. Cambridge: Cambridge University Press.

ANES, G. (1970). Las crisis agrarias en la España moderna. Madrid:Tecnos.

Aymard, M. (1973). Rendements et productivité agricole dans l'Italie moderne. Annales. Économies, Sociétés, Civilisations, 28 (2), 475-98.

Brumont, F. (1979). Comptes d'exploitations et histoire économique: L'exemple de la "granja" de Quintanajuar (1625-1835). Mélanges de la Casa de Velázquez, (15), 385413.

BRUMONT, F. (1985). Une exploitation en faire-valoir direct: La grange d'Hocina (16851707). In J. P. AmAlRIC \& P. PONsoT (Dirs.), L'exploitation des grands domaines dans l'Espagne d'Anciene Régime (pp. 133-60). Paris: CNRS.

Clark, G. (2007). A Farewell to Alms: A Brief Economic History of the World. Princeton: 
Princeton University Press.

Del Panta, L. \& Livi Bacci, M. (1977). Chronologie, intensité et diffusion des crises de mortalité en Italie: 1600-1850. Population, (32), 401-46.

FLINN, M.W. (1974). The Stabilisation of Mortality in Preindustrial Western Europe. The Fournal of European Economic History, 3 (2), 285-318.

García Sanz, A. (1985). La grange de Nieva, du monastère du Parral (Ségovie), entre 1739 et 1808. In J. P. AMALRIC \& P. PONSOT (Dirs.), L'exploitation des grands domaines dans l'Espagne d'Anciene Régime (pp. 193-221). Paris: CNRS.

Goubert, P. (1960). Beauvais et le Beauvaisis de 1600 à 1730: Contribution à l'histoire sociale de la France au XVIr siècle. Paris: S.E.V.P.E.N.

Goubert, P. (1965). La mortalité en France sous L'Ancien Régime: Problèmes et hipothéses. In P. HARsin \& E. Helin (Eds.), Problèmes de mortalité:Actes du Colloque international de démographie historique (Liège, 18-20 avril 1963) (pp. 79-92). Paris: Génin.

Grenier, J.Y. (1996). L'économie d'Ancien Régime: Un monde de l'échange et de l'incertitude. Paris: Albin Mitchell.

Instrucción de un passagero para no errar el camino: Escrita para consuelo de los que caminan desde la primera entrada hasta la última salida (1697). Madrid: Imprenta Diego Martínez Abad.

LABrousse, E. (1962). Fluctuaciones económicas e historia social. Madrid:Tecnos.

LLOPIS, E. (1989). El agro extremeño en el Setecientos: Crecimiento demográfico, "invasión mesteña" y conflictos sociales. In Estructuras agrarias y reformismo ilustrado en la España del siglo XVIII (pp. 267-90). Madrid: Ministerio de Agricultura, Alimentación y Medio Ambiente.

Llopis, E. \& SEBASTIÁN, J. A. (2019). Aclarando tintes demasiado oscuros: La economía española, 1700-1799. Cuadernos Dieciochistas (20).

Llopis, E., Pérez Moreda, V. \& Sebastián, J. A. (2015). Algunas sombras en el Siglo de las Luces: La sobremortalidad adulta en el interior castellano a mediados del Setecientos. In J. L. García Ruiz \& J. M. Ortiz Villajos (Eds.), Ensayos de Historia y Pensamiento Económicos. En homenaje al profesor Fuan Hernández Andreu (pp. 6982). Madrid: Delta.

Llopis, E., Sebastián, J. A., Bernardos, J. U., Velasco, A. L. \& Abarca, V. (2018a).

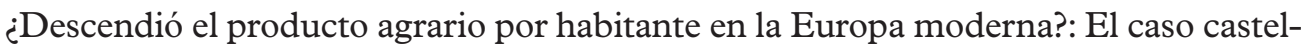
lano. Investigaciones de Historia Económica, 14 (2), 69-81.

Llopis, E., Sebastián, J. A., Sánchez Salazar, F., Abarca, V. \& Velasco, A. L. (2018b). La mortalidad junto a una gran urbe: El área rural madrileña en los siglos XVIII y XIX. Asociación Española de Historia Económica, (DT-AEHE-1805), 1-41.

Malanima, P. (2011). The Long Decline of a Leading Economy: GDP in Central and Northern Italy, 1300-1913. European Review of Economic History, 15 (2), 169-219. 
Meuvret, J. (1946). Les crises de subsistances et la démographie de la France d'Ancien Régime. Population, 1 (4), 643-50.

Meuvret, J. (1965). Demographic Crisis in France from the Sixteenth to the Eighteenth Century. In D. V. Glass \& D. E. C. Eversley (Eds.), Population in History: Essays in Historical Demography (pp. 507-22). London: Edward Arnold.

Morineau, M. (1970). Les faux semblants d'un démarrage économique: Agriculture et démographie en France au XVIII siècle. Paris: Armand Colin.

Ó GrádA, C. (2009). Famine: A Short History. Princeton: Princeton University Press. PÉReZ MoredA, V. (2010). Una nueva interpretación de las relaciones entre mortalidad y economía: Pruebas históricas en contra del modelo de las "crisis de subsistencias". In S. CAVACIOCCHI (Ed.), Le interazione fra economia e ambiente biologico nell'Europa preindustriale, secc. XIII-XVIII (pp. 181-218). Firenze: Firenze University Press.

Ponsot, P. (1969). En Andalousie occidentale: Les fluctuations de la production du blé sous l'Ancien Régime. Études rurales, (34), 97-112.

Ponsot, P. (1982). Malthus n'etait il pas prophète en Andalousie?: Les rendements des cereals en Basse Andalousie, XVII $\mathrm{e}^{\mathrm{e}} \mathrm{XIX}^{\mathrm{e}}$ siècles. In J. Goy \& E. LE Roy LADURIE (Eds.), Prestations paysannes, dîmes, rente foncière et mouvement de la production agricole à l'èpoque préindustrielle (pp. 431-46). Paris/La Haye/New York: Mouton.

Ponsot, P. (1986). Atlas de historia económica de la Baja Andalucía: siglos XVI-XIX. Sevilla: Editoriales Andaluzas Unidas.

SAAVEDRA, P. (1987). La economía del monasterio de Carracedo; ca. 1700-1834. Studia Histórica: Historia Moderna, (5), 241-82.

SERRÃo, J. V. (2007). A agricultura portuguesa no século XVIII: Progresso ou atraso? In M. MоттA (Org.), Terras lusas: A questão agraria em Portugal (pp. 31-70). Rio de Janeiro: Editora da UFF.

SERRÃO, J.V. (2017). Extensive Growth and Market Expansion. In D. FreIRE \& P. LAINS (Eds.), An Agrarian History of Portugal, 1000-2000: Economic Development on the European Frontier (pp. 132-70). Leiden/Boston: Brill.

ZANDEN, J. L.van (2009). The Long Road to the Industrial Revolution:The European Economy in a Global Perspective, 1000-1800. Leiden/Boston: Brill. 
STATISTICAL APPENDIX

TABLE A

Intensity of the crises of wheat yields in eight farms and estates (\%)

\begin{tabular}{|c|c|c|c|c|c|c|c|c|}
\hline Period & El Rincón & La Burguilla & Madrigalejo & La Vega & Quintanajuar & Matallana & Panguía & Rinconada Alta \\
\hline 1700 & 33.59 & 53.97 & & & & & & \\
\hline 1702 & 28.33 & 36.99 & 49.75 & 53.30 & & & & \\
\hline 1703 & 39.48 & & & & & 32.99 & & \\
\hline 1706 & 70.54 & 61.70 & 49.10 & 50.32 & & 49.03 & 37.22 & 31.74 \\
\hline 1707 & 77.70 & & 38.56 & 50.32 & & 45.41 & & \\
\hline 1708 & 56.36 & & 71.96 & 61.99 & 31.11 & 51.62 & 43.42 & 51.63 \\
\hline 1709 & & & & & & 76.46 & & \\
\hline 1710 & 42.03 & 33.60 & 64.01 & & & & 39.85 & 47.48 \\
\hline 1711 & & & 63.69 & 55.29 & & & & \\
\hline 1712 & 46.33 & & & 31.69 & & & & \\
\hline 1713 & 49.19 & & & 37.90 & & & & 59.08 \\
\hline 1714 & & & & 53.05 & & & & \\
\hline 1715 & 55.72 & 36.43 & 25.43 & & & 78.27 & 25.43 & \\
\hline 1717 & & & & & 26.57 & & & \\
\hline 1718 & 42.03 & 33.41 & & & & 40.75 & 53.03 & \\
\hline 1721 & 57.64 & & & & 40.99 & & & \\
\hline 1722 & & 59.44 & 71.63 & 76.40 & & 37.91 & 38.15 & 48.48 \\
\hline 1723 & & & & 47.59 & & & & \\
\hline 1724 & & & & & & 50.32 & & \\
\hline 1726 & & 37.18 & & & & & & 49.47 \\
\hline 1727 & & & & 42.87 & & & & \\
\hline 1728 & & & & 37.15 & & & & 31.58 \\
\hline 1729 & & & & & 43.13 & & & \\
\hline 1730 & & & & & 31.38 & & 51.01 & 33.24 \\
\hline 1731 & & & & & 46.60 & & & \\
\hline 1732 & & & & 27.22 & 64.49 & 36.35 & & \\
\hline 1733 & 37.57 & & 50.72 & 63.24 & 66.62 & 27.04 & & \\
\hline 1734 & 30.40 & 94.53 & 63.53 & 77.39 & & & 51.94 & 73.99 \\
\hline 1735 & & & & & 46.60 & & & \\
\hline 1736 & 56.84 & & 60.61 & & 43.66 & & & 37.05 \\
\hline 1737 & 72.29 & 74.16 & 90.27 & 53.30 & 46.60 & & 69.28 & 71.07 \\
\hline 1738 & & 64.72 & & & 43.40 & & & \\
\hline 1739 & 34.38 & & & & 46.60 & & 29.00 & 54.11 \\
\hline 1740 & 64.80 & & & & 43.40 & & & \\
\hline
\end{tabular}




\begin{tabular}{|c|c|c|c|c|c|c|c|c|}
\hline Period & El Rincón & La Burguilla & Madrigalejo & La Vega & Quintanajuar & Matallana & Panguía & Rinconada Alta \\
\hline 1741 & & & & & 31.38 & & & \\
\hline 1742 & & & & & 30.58 & & & \\
\hline 1744 & & 44.54 & & 59.01 & & & & \\
\hline 1746 & & & & & 48.47 & & & \\
\hline 1747 & & 26.81 & & 26.72 & 56.75 & & & \\
\hline 1748 & & 36.24 & & & & 30.66 & & \\
\hline 1750 & & & & & & 28.59 & 78.61 & 82.11 \\
\hline 1753 & 81.53 & 66.80 & 84.11 & 71.93 & & 72.83 & 57.68 & 77.14 \\
\hline 1754 & & & 44.24 & & & 43.34 & 77.83 & 69.19 \\
\hline 1756 & & & & & & & 27.76 & \\
\hline 1758 & & & 32.89 & 62.74 & & & & \\
\hline 1759 & & & 76.01 & & & & & \\
\hline 1760 & & 43.41 & & & & 44.37 & & \\
\hline 1762 & 52.86 & & 37.91 & & & & & \\
\hline 1763 & & & 33.21 & & & & & \\
\hline 1764 & & & & 62.74 & & & & \\
\hline 1765 & & & 51.21 & 92.05 & & & & \\
\hline 1767 & & 27.75 & 85.41 & 75.16 & & 50.84 & 40.32 & 46.32 \\
\hline 1768 & & & 53.96 & & & & 27.61 & 40.03 \\
\hline 1769 & & 59.63 & & & & & & \\
\hline 1771 & 27.85 & & & & & & & \\
\hline 1772 & & 53.78 & 45.21 & 25.48 & & & 50.55 & 48.15 \\
\hline 1773 & & 40.58 & & & & & 41.25 & \\
\hline
\end{tabular}

Sources: see Table 1 . 